Portland State University

PDXScholar

\title{
Sustainability Education as a Framework for Enhancing Environmental Stewardship in Young Leaders: An Intervention at Tryon Creek Nature Day Camp
}

Andrea Nicole Lawrence Portland State University

Follow this and additional works at: https://pdxscholar.library.pdx.edu/open_access_etds

Part of the Environmental Health and Protection Commons, Other Environmental Sciences Commons, and the Science and Mathematics Education Commons

Let us know how access to this document benefits you.

\section{Recommended Citation}

Lawrence, Andrea Nicole, "Sustainability Education as a Framework for Enhancing Environmental Stewardship in Young Leaders: An Intervention at Tryon Creek Nature Day Camp" (2012). Dissertations and Theses. Paper 555.

https://doi.org/10.15760/etd.555

This Thesis is brought to you for free and open access. It has been accepted for inclusion in Dissertations and Theses by an authorized administrator of PDXScholar. Please contact us if we can make this document more accessible: pdxscholar@pdx.edu. 
Sustainability Education as a Framework for Enhancing Environmental Stewardship in Young Leaders: An Intervention at Tryon Creek Nature Day Camp

\author{
by \\ Andrea Nicole Lawrence
}

A thesis submitted in partial fulfillment of the requirements for the degree of

\author{
Master of Science Teaching \\ in \\ General Science \\ Thesis Committee: \\ Michael Flower, Chair \\ Stephanie Wagner \\ Cary Sneider
}

Portland State University

(C)2012 


\begin{abstract}
UNESCO established Sustainability Education as a top priority when it declared $2005-2014$ to be the global decade for sustainability. Sustainability education can be implemented in outdoor programs such as nature summer camps in order to build environmental stewardship and ecological literacy in counselors and campers. This study sought to determine the extent to which an ecology and leadership training given to assistant counselors at Tryon Creek State Natural Area day camp achieved the goals of sustainability education - for the assistant counselors to learn about ecology, develop stewardship attitudes and behaviors toward the environment, and become positive role models for the campers in their care. Knowledge and environmental stewardship attitudes and behaviors of the counselors were assessed using surveys, interviews, and training journals. A statistically significant difference was found between pre and posttest scores on a survey measuring knowledge of Pacific Northwest ecology, but no significant difference was found between the pre and posttest scores on an environmental attitudes survey, possibly due to a ceiling effect. Interviews revealed that participants learned about invasive species, Oregon flora and fauna, and stream ecology over the summer. Despite the results on the attitudes survey, interviewees reported greater environmental awareness at the end of the summer as well as a greater sense of place in nature and a desire to continue working with children in an outdoor setting.
\end{abstract}




\section{Acknowledgments}

I would like to thank the staff of the Friends of Tryon Creek, as well as the rangers from the Oregon Parks and Recreation Department, for their efforts to sustain a healthy forest and excellent recreational setting at Tryon Creek State Natural Area. Their support and patience throughout my study was invaluable. I would also like to thank the assistant counselors and participants of my study for their hard work at camp and their flexibility and willingness to help with the study. The guidance and feedback from my committee, Stephanie Wagner, Cary Sneider, and Michael Flower, was instrumental—big thanks. Thanks also to Laurie Cremona for her expert assistance in running the statistical analyses and figuring out how to organize the data. Finally, thanks to my family, friends, and peers in the Master of Science Teaching program for their support and good humor during this challenging process. 


\section{Table of Contents}

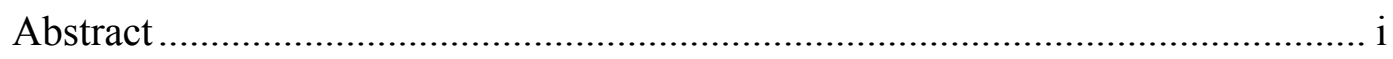

Acknowledgements .............................................................................. ii

List of Tables ....................................................................................... iv

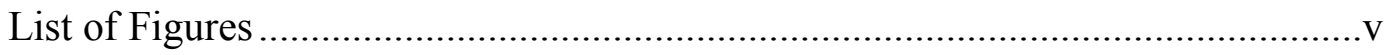

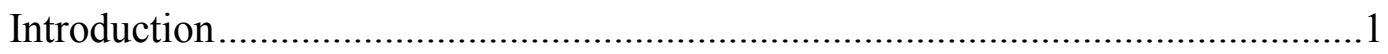

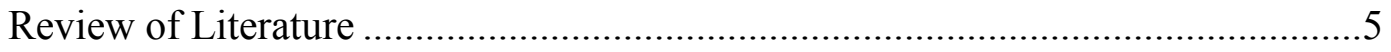

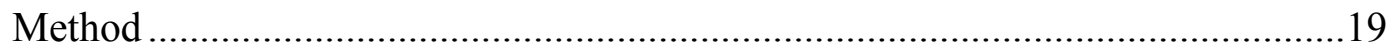

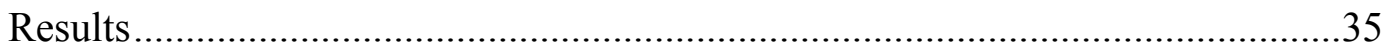

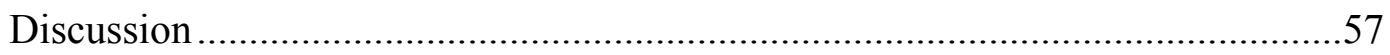

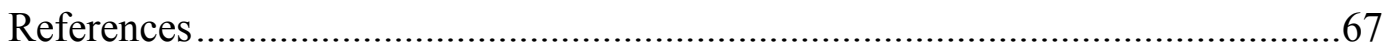

Appendices

A. Journal from Ecology and Interdependence Training Program ............70

B. Lesson Plans for the Training Program ..............................................85

C. Ecology and Interdependence Questionnaire (EIQ).........................88

D. Markscheme Scoring Guide for the EIQ........................................90

E. New Ecological Paradigm (NEP) Scale Form..................................92

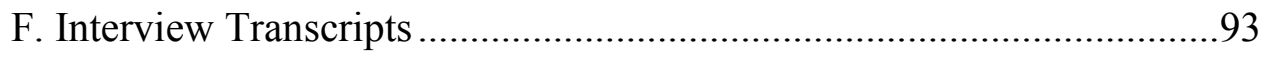

G. EIQ Scores for the Control Group ..............................................113 


\section{List of Tables}

1. Timeline and Experimental Design of the Study ..............................................20

2. Experimental Group: Profile of Participants of the Training Program......................22

3. Profile of Interviewees from the Control Group ................................................24

4. Comparison of EIQ Pre and Posttest Scores of All Participants .............................35

5. Comparison of EIQ Pre and Posttest Scores by Question .....................................37

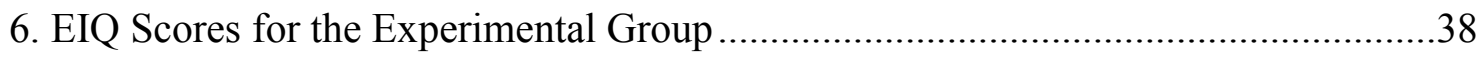

7. New Ecological Paradigm Scale: Relative Environmental Attitudes Analysis .........44

8. Comparison of NEP Scale Pre and Posttest Weighted Totals for All Participants.....45

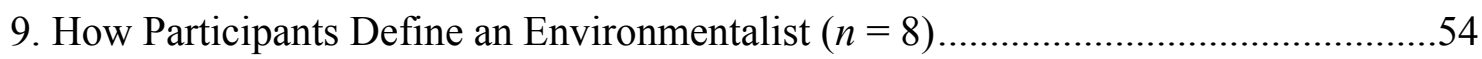




\section{List of Figures}

1. Ecology and Interdependence Questionnaire (EIQ) Scores..................................36

2. Ecology and Interdependence Questionnaire (EIQ) Scores on Question 4 ...............37 


\section{Introduction}

In light of large scale, global environmental crises such as climate change, habitat destruction and resource scarcity, sustainability education is an emerging global priority (Colucci-Gray, Camino, Barbiero, \& Gray, 2006). UNESCO has labeled 2005-2014 as the global decade for sustainability, helping to push educators to investigate how sustainability education can be incorporated into classroom and outdoor teaching strategies (Lugg, 2007). As youth come of age in a rapidly changing world, they need to develop the skills to address the environmental concerns of today and tomorrow. A considerable body of research indicates that using the framework of sustainability education (SE) to introduce the science of environmental issues will allow students to understand the issue in a well rounded manner and in a way that develops their critical thinking skills and abilities to creatively suggest ways to transform problems into winwin situations (Colucci-Gray et al., 2006; Lugg, 2007).

The Bruntland Commission defines sustainable development as “development that meets the needs of the present without compromising the ability of future generations to meet their own needs" (Bruntland, 1987, p.47). Similarly, David Orr suggests that "A sustainable society... does not undermine the resource base and biotic stocks on which its future prosperity depends" (Orr, 1992, p.23). It follows then, that sustainability education is a methodology by which students are taught the critical thinking skills necessary to understand environmental issues and create solutions that satisfy current needs and preserve resources and environmental integrity for the benefit of future generations. 
Sustainability education uses a multidisciplinary approach to understanding science and environmental issues (Burns, 2011; Lugg, 2007; Orr, 1992; Sterling, 2002). Students develop critical thinking skills using wisdom from science, philosophy, sociology, literature, politics, economics, and indigenous ways of knowing. These critical thinking skills can then be applied to a multitude of real world problems and challenges - students' understanding is not limited to the few examples that they discussed in a classroom. Along with a broad understanding of science concepts and environmental concerns, students explore the views and perspectives of many groups and stakeholders. For example, if students are discussing the dilemma of whether or not to remove mangrove habitat to farm shrimp on tropical coastlines, student may investigate the concerns of policy makers, shrimp farmers, local tourism providers, and various other stakeholders of those communities (Colucci-Gray et al., 2006). Additionally, SE utilizes place-based education through which students develop an intimate knowledge of, and more importantly, a deep concern and sensitivity for a local natural area (Burns, 2011; Lugg, 2007; Orr, 1992, 2005). Without this component of stewardship for the environment, students of SE will not be motivated to put their knowledge into action and care for the environment (Gilbert, 2003; Lugg, 2007; Orr, 1992; Preston \& Griffiths, 2004). Finally, SE courses and programs are designed following ecological principles or concepts such as: networks, nested systems, interdependence, diversity, cycles, flows, development, and dynamic balance (Burns, 2011; Capra, 2005).

As students develop critical thinking skills, a deep understanding of environmental issues, and acknowledge the needs of different groups of people they 
become increasingly ecologically literate. David Orr explains that "Ecological literacy...implies a broad understanding of how people and societies relate to each other and to natural systems, and how they might do so sustainably" (Orr, 1992, p.92).

Ecological literacy incorporates not only an understanding of the science of ecology, but also of how humans impact the natural world, and how humans and nature can interact harmoniously. As today's youth come of age in a rapidly changing world, they must be ecologically literate in order to meet UNESCO's goal of building a more sustainable society. One logical place for youth to gain ecological literacy is through outdoor and environmental education programs.

Teenagers are especially responsive to outdoor experiences and service learning opportunities that allow them to spend time in nature away from normal daily school activities (Roberts \& Suren, 2010). High school camp counselors are in a special role of both student and teacher - they are at a pivotal time in their life when they are developing daily living habits and making career choices, and they are in a place to be big brother or sister type role models for the young campers in their care.

This study included an educational program for assistant day camp counselors at Tryon Creek State Natural Area. Using the framework of sustainability education (Burns, 2011), the program presented forest ecology concepts and outdoor leadership and teaching techniques. The goals of the program were for counselors to gain ecological content knowledge, develop a sense of environmental stewardship, and learn how to educate others on the importance of caring for the natural environment. 
The research question addressed by this study is: How do sustainable ecology training programs and leadership experience at a nature day camp impact teens’ 1) knowledge of ecology, 2) environmental stewardship attitudes and behaviors, and 3) ability to be a positive leader for young people in an outdoor setting? Surveys, interviews, and training journals kept by the camp counselors were used to determine the extent to which the training program and camp experience helped the counselors learn ecological principles (knowledge), and become better stewards of the environment and role models for their campers in their care (attitudes and behaviors). 


\section{Review of Literature}

This review begins by examining studies that address sustainability education pedagogies that include science or environmental education. Next, several studies that investigate how outdoor experiences relate to environmental attitudes and behaviors will be examined. Finally, two more studies will be discussed that look at the impacts of environmental education interventions on pre-service teachers' self-efficacy.

\section{Sustainability and Environmental Education}

Burns (2011) presents an overview of her model of sustainability education in order to provide practical ways for educators to design sustainability courses. The goal of the Burns model of sustainability pedagogy is to promote transformational learning that empowers students to be able to solve complex problems and work to revive sustainable communities. The model contains five interdependent elements: content, perspectives, process, context, and ecological design. Burns recommends that content be centered on a multidimensional sustainability theme such as sustainable watersheds or education for livable cities. The content is presented through diverse perspectives that consider complex ecological and social issues and question dominant norms. The teaching and learning process is participatory and experiential and offers opportunities for civic engagement through service learning projects. The context of the course is place-based, or rooted in the community where the learning is happening, and embraces complexity and interrelatedness. Finally, design based on ecological principles weaves together the other four elements of the Burns model. The ecological design utilizes a simple, non- 
linear process originally intended for permaculture gardening: 1) observation, 2)

visioning, 3) planning, 4) development, and 5) implementation. The Burns model served as the main tool for designing and implementing the sustainable ecology and leadership training in this study.

Lugg's (2007) review of more than 50 research articles found evidence to support her thesis that sustainability literacy is essential and can be gained through outdoor education experiences, particularly in higher education. In light of the current Decade for Education for Sustainable Development, there is pressure for higher education institutions to incorporate sustainability education (SE) into their curricula and pedagogies. The article identified several barriers to incorporating SE into higher education, such as the difficulty of establishing interdisciplinary curricula across university departments and the shifting priorities of administration. Lugg proposed that outdoor education may help surmount some of the barriers keeping SE out of university programs since it fosters sustainability literacy in students by promoting environmental and community awareness, and providing opportunities for sensory, cognitive, and affective learning. Furthermore, a stronger sense of place can be established in outdoor education programs - students may revisit the same area over a span of time gaining an intimate knowledge and appreciation of the area. Lessons can also be framed in terms of the ecology and terrain of the location rather than purely upon a set curriculum. Lugg concluded that outdoor education has the possibility to be a vehicle for sustainability education, but curricula, pedagogical strategies, and research are lacking. Investigating 
the possibility of using outdoor education to promote sustainability literacy is an area ripe for research.

Colucci-Gray et al. (2006) conducted a literature review of 97 articles and an action-research project in order to combine components of science and sustainability literacy and non-violent conflict transformation to form a model for teaching students how to respond to global socio-environmental conflicts. The researchers sought to address "how science education responds to the need of preparing citizens to act in the new global context” (Colucci-Gray et al., 2006 p.229). Colucci-Gray et al. emphasized the central role of complexity in terms of the multiple viewpoints and ways of understanding and dealing with large scale environmental conflicts. Additionally, they proposed the use of complexity in pedagogy — that teachers facilitate activities that utilize student participation, the sharing of multiple perspectives, the acknowledgement of multiple "truths" and possible solutions, and meta-reflection throughout the learning process. The researchers conducted an action research project using role-play activities as a strategy for teaching students how to approach large-scale socio-environmental conflicts. The students were given the role of a stakeholder and asked to research various aspects of the conflict, in this case the destruction of mangrove coastal habitat for shrimp farming in the southern hemisphere. Students gathered information on the scientific, as well as economical, social, and political components of the conflict. The first iteration of the role-plays was a simulation of a public debate - the students would present two or three of the main viewpoints to a panel of judges who would favor one solution. The researchers found that this model for the role-plays did not produce the results they had 
hoped for. Because the scenario resulted in a win-lose situation, the students were focused on getting others to agree with their point of view, rather than listening to each stakeholder and coming to a consensus. In accordance with current notions of the epistemology of science as well as sustainability education, the authors wanted the students to be able to recognize that there is a multiplicity of legitimate views in science, to participate in dialogue rather than debate, and to acknowledge that conflicts generally cannot be solved, but can be transformed over time through cooperation and creativity. The researchers facilitated the second round of role-plays with a focus on how the conflict was recognized and handled. This time students focused on the process rather than the product, and used active listening, reflection, and creativity to transform the conflict into a win-win situation. The role-play activity described in Colucci-Gray et al. (2006) served as the model for a similar activity used in the training program of this study.

Gilbert (2003) conducted a literature review of 26 articles in order to assess whether ecotourism is a form of environmental education for sustainability. Gilbert found that current forms of environmental education through ecotourism do not measure up to the current standards for sustainability education, which incorporates cultural and social information and emphasizes values, equity, and diversity. Gilbert suggested using critical discourse analysis as a teaching approach in order to make environmental education more consistent with today's standards for sustainability. Finally, the researcher asserted that discourse analysis would shed light on how conventional wisdom may constrain people's views and behaviors surrounding environmental sustainability, and present alternative 
views that promote justice, well-being, and conservation-ideas that are consistent with the current definition of sustainability. In light of Gilbert's (2003) findings, the training program in this study incorporated activities in which students were asked to consider

diverse and unconventional perspectives on topics such as land management and food systems.

\section{Environmental Attitudes and Outdoor Experiences}

Roberts and Suren (2010) conducted a qualitative study in which they evaluated two youth leadership programs at the Crissy Field Center (CFC) near San Francisco, California. The researchers investigated how participants developed leadership skills and environmental stewardship behaviors, and how their academic and career choices were influenced through participation in the programs. The programs were for middle and high school students and involved environmental studies and leadership lessons, outdoor recreational field trips, and field restoration projects. The CFC staff members were especially concerned with providing outdoor experiences to diverse urban youth in order to promote sustainable living practices within local, underserved communities of the San Francisco Bay Area. Focus group interviews were conducted with 43 participantscurrent and former participants of the two programs. The authors chose to do group interviews so that the interaction within the group could provide insights that may not have come out in individual interviews. The interviews were video recorded and analyzed using a constant-comparison method to determine emerging themes and patterns between participant responses. Six main themes emerged: motivation to join the program, 
contribution to the environment, social awareness and outreach, personal growth and leadership, aided school performance, and healthy lifestyles. Roberts and Suren found that the participants learned about environmental science and ethics, shared these lessons with their communities through speaking out and taking on leadership roles, and adopted stewardship attitudes and behaviors. The authors suggested that in and out of school experiences should complement and inform one another, and that urban youth should have regular exposure to the natural world in order to encourage new, sustainable, habits.

Stern, Powell, and Ardoin (2008) conducted a quasi-experimental study in order to evaluate a residential environmental education program at the Great Smoky Mountains Institute in Tremont, Tennessee. The researchers developed survey instruments in order to measure short- and medium-term attitude and behavior impacts of the program in the context of the following themes: connection with nature, environmental stewardship, interest in learning and discovery, and knowledge and awareness of Great Smoky Mountains National Park. Stern et al. compared the impacts of 3 and 5 day programs and investigated the role that teacher involvement and preparation played in student outcomes. Students in grades 4-7 who visited Tremont during the 2006-2007 school year were selected by their teachers to participate in the surveys. The first survey was given as students arrived, the second at the end of the last activity, and the third survey was administered by classroom teachers in their schools 3 months following the stay in the Great Smoky Mountains. 273 students responded to the pre and post surveys, and 183 responded to the pre, post, and delayed post surveys. Stern et al. used paired $t$ tests to analyze the survey data. They found that students showed statistically significant gains in 
all four areas in the short term, but that only stewardship and awareness gains persisted after three months. When the authors compared gains between students participating in 3 day and 5 day programs they found that students who stayed for the longer session showed greater short term gains in stewardship, interest in discovery, and awareness scores, and greater long term gains in awareness scores. The researchers also found that students showed more positive outcomes when their classroom teachers were involved in teaching activities at the environmental education center and had done preparatory lessons in the classroom. Stern et al. were also surprised to find that students in larger groups seemed to get more out of the program than students in smaller groups. The authors concluded that longer environmental education programs with follow-up classroom visits, and greater teacher preparation and involvement are likely to enhance the long-term benefits of participation in residential environmental education programs.

Preston and Griffiths (2004) conducted a collaborative action research project in order to evaluate and refine a pedagogical intervention on place-based education in which participants developed connections with a natural area through several "ways of knowing." The research project was part of a three month outdoor education course for sixteen graduate students studying environmental education. Students in the course made four visits of two hours or longer to an individually chosen natural area in order to get to know the place through various frames, or ways of knowing, such as scientific/ecological, experiential, historical, artistic, etc. Students recorded and reflected upon their experiences through guided journaling and discussion with the rest of the class. Journal entries and discussion dialogue served as the authors' qualitative data. In 
searching for patterns in the data, the authors hoped to determine how successful their teaching methods were, which experiences were most valuable for their students, and whether students were able to develop praxis (turning the theory of connection to place into practical teaching strategies). Almost all of the participants noted a change in the way that they connected with their chosen place after completing the visits. Most students found that the experiential way of knowing was particularly powerful, but that a scientific way of knowing helped them pay attention to small, seemingly insignificant details, and that the historical frame allowed them to connect through stories and finding their own roots in the place. The authors reflected on the pedagogy of the course, noting the benefits of a learner-centered approach, building reflective and descriptive skills, and raising student awareness of social and cultural influences such as the lack of perceived importance of connecting with nature and everyday pressures to stay on a rigid, linear time schedule. Almost all of the participants noted the practical application that their experience had for their future outdoor and environmental teaching strategies. The authors concluded by emphasizing the importance of the intensity of a connection experience and value of using varied teaching strategies and ways of knowing to engage students in a natural area.

Thapa (2010) conducted a quasi-experimental study in order to shed light on the relationships between environmental attitudes and behaviors and participation in various outdoor recreation activities. Thapa reasoned that outdoor recreation participation is increasing and that if participants are more likely to foster environmental stewardship attitudes and behaviors, then funding and promoting outdoor recreational opportunities 
and facilities would be an effective way to protect the natural environment. The study was conducted in Bald Eagle State Forest in central Pennsylvania where several different types of outdoor recreation are possible for visitors. The researchers divided the forest into zones and sampling sites $(n=13)$ and conducted on-site intercept surveys during the summer (June - October) and "windshield" surveys during the winter (October - March) due to weather conditions. The people surveyed were provided a letter about the study, a questionnaire, and a pre-paid envelope and asked to answer the questions at home and return the packet to the researchers. The response rates were $52 \%$ and $23 \%$ for the summer and winter samplings, respectively. There were a total of 522 respondents $-87 \%$ were males and 99\% were Caucasian. Respondents were asked to name their "most important activity" in outdoor recreation - their choice was used to place them in the category of appreciative, consumptive, or motorized outdoor recreationist. The respondents also rated statements about environmental attitudes (using the New Ecological Paradigm scale) and behaviors (mostly derived from the Environmentally Responsible Behavior Index) on a Likert scale, and these responses were subjected to principal components analyses. Environmental attitudes were found to fall under the factors of Ecocentric, Dualcentric, and Technocentric, and environmental behaviors were factored as Political Activism, Recycling, Educational, Green Consumerism, and Community Activism. The relationships between all of these categories and factors were analyzed using a series of linear regressions in order to see if outdoor recreation participation mediated environmental attitudes and behaviors. Thapa found that outdoor recreation participation did mediate the relationship between environmental attitudes and 
behaviors, but only for appreciative and motorized recreationists, and only for a few types of behaviors. These relationships were less powerful than the direct effects that attitudes had on behaviors. Thapa suggested that future studies should be conducted at other recreation sites with a more diverse sampling, and that environmental education should be targeted towards groups of recreationists that have notoriously low environmental ethics (in this study those with consumptive recreation preferences and/or a technocentric attitude).

\section{Environmental Education Interventions and Self-Efficacy}

Carrier (2009) conducted a retrospective case-study in order to see how and why pre-service teachers gained self-efficacy by teaching outdoor science lessons to elementary school students during a science methods course. Through reviewing literature, Carrier found that most pre-service elementary teachers lack confidence in teaching science because their academic background is in other subjects and they lack experience in doing science. The author suggested that by teaching in an authentic learning setting such as the outdoors, pre-service teachers gain experience and consequently build self-efficacy in teaching science. Carrier examined the impacts of a two week long field experience in which pre-service teachers went to a local forest preserve to observe and teach science lessons to elementary age students at a summer day camp. Three types of data were collected: student statements in final reflection papers for the methods course, observational field notes from the summer camp, and follow-up interviews with the pre-service teachers seven months following the field experience. 
Carrier found that the pre-service teachers did have increased self-efficacy in teaching science after the field experience, largely due to seeing how the students responded with great enthusiasm to their instruction. The pre-service teachers also discovered that the outdoors was a good setting to teach science- the classroom was not the only place where learning occurred. All of the pre-service teachers expressed interest in teaching science in an outdoor setting, but seven months later, a few found barriers to doing so in their student teaching because their supervising teachers refused to adapt lessons to an outdoor setting. The author concluded that a critical experience for the pre-service teachers was having effective science teaching modeled and seeing the enthusiasm that the students had for learning science. Furthermore, the pre-service teachers were able to learn alongside their students and see the ubiquity of science and how it related to their lives and the lives of their students.

Moseley, Reinke, and Bookout (2002) conducted a quasi-experimental study in order to examine the effect that teaching for an outdoor, environmental education program had on the self-efficacy and outcome expectancy of pre-service teachers. Through a review of literature, Moseley et al. found that environmental education is becoming more popular in elementary schools, but teachers often think that they lack the knowledge, experience, and confidence to teach environmental education, particularly outdoors. The researchers investigated whether participation in their ABC program (Adventures Beyond the Classroom) would increase preservice teachers'self-efficacy and outcome expectancy for environmental education instruction. $\mathrm{ABC}$ is an outdoor environmental education partnership program between a university teacher training 
program and a local public middle school. Pre-service teachers worked in teams to teach one or two activities four times during one day of the ABC program. The study was a based on pretest/2-posttest design, using the Environmental Education Efficacy Belief Instrument, which contains self efficacy and outcome expectancy statements that are rated with a 5-point Likert scale. The 72 participants were assigned to the experimental or control group based on their lab section. Pretest scores between the control and experimental group were not significantly different. Self-efficacy and outcome expectancy were not found to be significantly different between the groups, however time had a significant negative effect on self-efficacy, which according to the authors was probably due to the very short duration of the ABC program, the lack of further experience in environmental education after the program, and the fact that no feedback was given to the pre-service teachers.

\section{Summary}

There is both a space and need for increased research on and practice of sustainability education in the United States. The vast majority of current research in sustainability education is coming out of the UK and Austrailia (e.g. Colucci-Gray et al., 2006; Gilbert, 2003; Higgins, 1996; Higgins \& Kirk, 2006; Lugg, 2004; Preston \& Griffiths, 2004). Because sustainability is a global issue, research in sustainability education ought to include the perspectives of multiple regions and nations. Sustainability education approaches such as using multiple ways of knowing, place-based education, reflection, critical thinking, role-playing, and discourse analysis have found success 
abroad (Colucci-Gray et al., 2006; Gilbert, 2003; Lugg, 2007), and their possible benefits can be explored within the context of American society. Additional research, particularly within the American education system, can be simplified by using the Burns (2011) model of sustainability pedagogy, which provides a practical plan for educators to redesign existing courses to meet the goals of sustainability education. The Burns model was a major influence in designing the training intervention of this study.

Current research in environmental education has shed light on a great deal of what students gain from outdoor environmental learning, and what strategies and factors influence the quality of student learning in the outdoors. Students, particularly teens living in the inner city, have much to gain from outdoor environmental learning outside of the context of their daily life (Roberts \& Suren, 2010). Greater teacher preparation and involvement in environmental education can increase students' benefits from the experience (Stern et al., 2008). It then follows that providing a more in-depth and participatory training for assistant counselors at a nature day camp will lead toward better experiences for the campers. Pedagogy with a focus on facilitating teachers' sense of place in a natural setting can positively influence their perception of the environment and give them practical skills for future teaching (Preston \& Griffiths, 2004). Additionally, outdoor recreation experiences can directly impact the environmental stewardship attitudes of participants (Thapa, 2010).

Environmental education experience tends to increase teachers' self efficacy in teaching science (Carrier, 2009). Increased self efficacy also seems to increase teachers' desire and willingness to implement environmental education lessons and activities 
(Carrier, 2009). Seeing student enthusiasm and engagement in an outdoor setting is a large factor in why teachers gain confidence in their ability to teach science in a natural setting (Carrier, 2009). Short interventions may not have a noticeable impact on teacher self efficacy in teaching science outdoors (Moseley et al., 2002). Relatively long and indepth training or experience in environmental education is therefore more likely to build self efficacy in new environmental educators than participation in brief programs. As assistant camp counselors go through an in-depth training, gain skills in environmental education, and have positive interactions with campers, they will hopefully have increased self efficacy in teaching science, and will more likely have the confidence to discuss ecological issues with friends and family. 


\section{Method}

\section{Overview}

This study used the framework of sustainability education (Burns, 2011; Lugg, 2007; Sterling, 2002) and ecological literacy (Colucci-Gray et al., 2006; Orr, 1992) as the inspiration for a training intervention for assistant counselors at a nature day camp at Tryon Creek State Natural Area in Oregon. Participants spent a weekend learning about the ecology and environmental concerns of the park. Additionally, assistant counselors did activities intended to develop leadership, critical thinking and problem solving skills, a sense of place in the natural environment, and sensitivity to the social and cultural dimensions of both science and sustainability. The ultimate goal of the intervention and camp experience was for the assistant counselors to increase their ecological literacy and environmental stewardship and be positive role models for their campers.

The research question for this study is: How do sustainable ecology training programs and leadership experience at a nature day camp impact teens' 1) knowledge of ecology, 2) environmental stewardship attitudes and behaviors, and 3) ability to be a positive leader for young people in an outdoor setting? In order to answer this question, three types of data were collected: surveys, interviews, and participants' training program journals. The surveys were used to measure how well participants understand and apply ecological concepts, as well as their environmental stewardship attitudes. The interviews served to enrich the survey data and to provide insight into the participants' experiences of being a leader and environmental educator. The training journals included written 
exercises, guided reflections, and self assessments and were used to determine what the participants learned and gained from the training program.

Mixed methods with a quasi-experimental design were used for this study. Major themes were pulled from interview data using a method inspired by grounded theory (Glaser \& Strauss, 1967). The participants of this study were the assistant counselors at the Friends of Tryon Creek State Natural Area summer day camp. The assistant counselors are high school age volunteers from the Portland, Oregon metropolitan area that have an interest in the outdoors and working with children. Table 1 displays the experimental design of the study.

\begin{tabular}{|c|c|c|c|c|}
\hline \multicolumn{5}{|c|}{$\begin{array}{l}\text { Table } 1 \\
\text { Timeline and Experimental Design of the Study }\end{array}$} \\
\hline \multicolumn{5}{|c|}{ Treatments and observations from summer and fall 2011} \\
\hline Group & June $24 *$ & June $24-26$ & June $27-$ Aug 27 & July - Nov ** \\
\hline Experimental & $\mathrm{O}_{\text {pre }}$ & $\mathrm{X}_{\mathrm{T}}, \mathrm{O}_{\mathrm{J}}$ & $\mathrm{X}_{\mathrm{AC}}$ & $\mathrm{O}_{\text {post }}, \mathrm{I}$ \\
\hline Control & $\mathrm{O}_{\text {pre }}$ & & $\mathrm{X}_{\mathrm{AC}}$ & $\mathrm{O}_{\text {post }}, \mathrm{I}$ \\
\hline \multicolumn{5}{|c|}{$\begin{array}{l}\text { Note. } \mathrm{O}_{\text {pre }}=\text { Observations from two pretests, } \mathrm{X}_{\mathrm{T}}=\text { Training intervention, } \mathrm{O}_{\mathrm{J}}=\text { Observations from } \\
\text { training journals (written reflections and assessments), } \mathrm{X}_{\mathrm{AC}}=\text { Two weeks of assistant camp counseling } \\
\text { experience, } \mathrm{O}_{\text {post }}=\text { Observations from two posttests, } \mathrm{I}=\text { Interviews } \\
\text { *Some participants from the control group were not present on June } 24^{\text {th }} \text { and took the pretests on the } \\
\text { morning of their first day at camp. } \\
* * \text { The majority of the participants took the posttests at the end of their last day at camp. }\end{array}$} \\
\hline
\end{tabular}

\section{Study Site}

This study took place at Tryon Creek State Natural Area which is located in southwest Portland, Oregon. The area is a mid-successional stage forest and riparian area, dominated by Douglas-fir, western hemlock, western red cedar, big leaf maple, and red alder. Wildlife living at the park includes deer, coyotes, moles, squirrels, and several 
species of songbirds and birds of prey. The park has fourteen miles of trails which visitors use for nature hiking, horseback riding, and trail running. The Friends of Tryon Creek is a non-profit organization that shares responsibility with the Oregon Parks and Recreation Department in managing the natural area and providing educational programs for the general public.

\section{Participants}

During the summer, the Friends of Tryon Creek offers week-long day camps for elementary school age children. The campers spend about six hours each day hiking through the park and participating in nature themed activities and games. Groups are led by an instructor, an adult staff member with a background in leadership and nature education, as well as an assistant counselor (AC), a teen volunteer with an interest in working with children and the outdoors. Staff members typically work for the entire summer, whereas assistant counselors are only required to volunteer for a minimum of two weeks of camp. This study focused on the assistant counselors for two main reasons: 1) In the past, the assistant counselors have received very limited training, which did not include science content, and 2) The education director of the Friends of Tryon Creek expressed interested in improving the training for assistant counselors so that they have a better understanding of the ecology of the park and how to teach that information. This researcher was a staff instructor at the nature day camp during the summer that the study was conducted and worked directly with the participants of the study. 
The participants and experimental and control groups were selected through a sample of convenience. Each summer about forty assistant counselors work at the camp. All assistant counselors were invited to participate in both the study and the weekend training intervention at the beginning of the summer. Twenty-two assistant counselors agreed to participate in the study and completed pre and posttests. Four of those twenty two participants were able to attend the entire training program and served as the experimental group (see Table 2). The study participants who were unable to attend the

\begin{tabular}{|l|l|l|l|l|}
\hline \multicolumn{5}{|l|}{ Table 2} \\
Experimental Group: Profile of Participants of the Training Program \\
\hline Name* & Gender & Grade in fall & AC experience & Learning goals** \\
\hline Celia & female & Sophomore & 1 st year & $\begin{array}{l}\text { "To learn more about plants and } \\
\text { animals and just the history of Tryon." }\end{array}$ \\
\hline Hazel & female & Sophomore & 1 st year & $\begin{array}{l}\text { "To connect the previous knowledge } \\
\text { and experience I have from ODS } \\
\text { [Outdoor School] (and life) to the } \\
\text { whole ecosystem as well as } \\
\text { sustainability and life." }\end{array}$ \\
\hline Owen & male & Sophomore & 2nd year & $\begin{array}{l}\text { "To be able to appreciate the land } \\
\text { more and be able to identify local } \\
\text { plants and animals." }\end{array}$ \\
\hline Zoe & female & Senior & 2nd year & $\begin{array}{l}\text { "To learn more about the history of } \\
\text { Tryon and ...about the different plants } \\
\text { and animals and be able to identify } \\
\text { them. Also to become more familiar } \\
\text { with Tryon Creek Natural Area." }\end{array}$ \\
\hline
\end{tabular}

training served as the control group $(n=18)$. Unfortunately only a small portion of the participants were able to attend the training, but the training journals and interviews provided rich qualitative data on the learning and insights that the participants gained during the training and camp. 


\section{Procedure}

This study took place during the summer of 2011, coinciding with the day camp schedule at Tryon Creek State Natural Area. Pretests (one survey on ecological concepts and another on environmental attitudes) were administered to all participants of the study before they began either the weekend training (for the experimental group) or their first week of camp (for the control group). T-tests were used to compare the pretest scores of the experimental and control groups to determine the validity of the sample. No statistically significant difference was found ( $\mathrm{P}$-value $=0.145$ and 0.875 for the environmental attitudes and ecology surveys, respectively), indicating that the experimental group was a valid sample.

From June 24th -26 th, the experimental group received a training intervention consisting of ecology content, environmental education pedagogy, and leadership skills. Participant journals containing written exercises, guided reflections, and self assessments were copied and collected for analysis. The control group did not receive the training intervention; rather they received a brief session on group management skills or no training at all before they worked with the campers.

After the participants completed two weeks of camp counseling over the summer, they took posttests (identical to the pretests). In August and throughout the fall, eight interviews were conducted with the four participants in the experimental group as well as four participants from the control group. The four interviewees from the control group (Table 3) were selected based upon their availability and their varied backgrounds and perspectives. 


\begin{tabular}{|l|c|c|c|c|}
\hline $\begin{array}{l}\text { Table } 3 \\
\text { Profile of Interviewees from the Control Group }\end{array}$ \\
\hline Name* & Gender & Grade in fall & AC experience & Unique perspective \\
\hline Kate & female & Senior & 1 st year & $\begin{array}{c}\text { Liza's sister, has taken several science } \\
\text { classes in school }\end{array}$ \\
\hline Liza & female & Sophomore & 1 st year & $\begin{array}{c}\text { Kate's sister, aspires to be an overnight } \\
\text { camp counselor in the future }\end{array}$ \\
\hline Josh & male & Senior & 1st year & $\begin{array}{c}\text { Has worked as an Outdoor School } \\
\text { student leader }\end{array}$ \\
\hline Adam & male & Sophomore & 2nd year & $\begin{array}{c}\text { Lives adjacent to the park, involved in } \\
\text { outdoor activities and leadership with } \\
\text { the Boy Scouts }\end{array}$ \\
\hline *Pseudonyms have been assigned. &
\end{tabular}

\section{Treatment}

Before the beginning of camp, the experimental group of assistant counselors received a training intervention designed and led by this researcher. The overnight training program took place on the weekend of June 24th - 26th, 2011 and focused on the following themes: 1) ecology of Tryon Creek State Natural Area, 2) developing a sense of place in nature through multiple ways of knowing, 3) outdoor leadership and teaching skills, and 4) facilitation of camp games and activities. The learning objectives of the program were to enhance students' ability to: 1) explain in depth how to be an environmental steward and develop a sense of place in the natural world, and 2) describe living and non-living components of an ecosystem and explain how those components are interconnected.

The training was designed using the framework of sustainability education (Burns, 2011; Orr, 1992, Sterling, 2002) which seeks to address current sustainability concerns through understanding ecological principles, using an experiential and 
interdisciplinary approach, developing critical thinking skills through exploring multiple perspectives, and fostering a sense of place in the natural world. Additionally, Oregon state science standards (ODE, 2009) were incorporated into the ecology content of the training.

Specific topics presented in the training were related to the big idea of interdependence in natural ecosystems. David Orr eloquently stated that "The basis for ecological literacy...is the comprehension of the interrelatedness of life grounded in the study of natural history, ecology, and thermodynamics" (Orr, 1992, p. 93). The curriculum of the educational programming for the Friends of Tryon Creek, as well as the curriculum for the Multnomah Educational Service District (MESD) Outdoor School Program (Eng, 2006) were used to organize lessons and activities that would be relevant to the Tryon Creek site. Topics covered included: natural history, ethnobotany, plant-soilanimal interactions, fungi ecology, riparian ecology, environmental science (invasive species, water quality, and resource conservation), critical thinking and discourse regarding environmental issues, nature art and writing, history of land use at the park, and group facilitation skills. See Appendix A for a copy of the training journal given to the participants. The journal includes a detailed schedule of the weekend, activities, areas for guided reflection, and self-assessments. Appendix B contains detailed lesson plans for the training program.

All twenty two participants spent at least two weeks at Tryon Creek nature day camp in the role of an assistant counselor (AC). The ACs had ample opportunity to learn about the ecology and natural history of the park as well as environmental education 
techniques as they participated in hikes and activities and shadowed experienced staff members. Their role was to support the staff instructors by keeping campers engaged during themed nature hikes (themes included plants and animals found in different forest layers, water quality monitoring, energy and nutrient flows through the forest, and natural science inquiry). ACs also helped lead afternoon activities ranging from nature art to learning about animal pelts and skulls to field games. Hikes and activities were planned by staff instructors, so the specific information that ACs were exposed to varied, but each AC had the opportunity to work with a different staff member each week and choose which afternoon activities they would like to help with. Many ACs also had the opportunity to work with State Park rangers during afternoon Jr. Ranger programs, during which they learned about topics such as animal tracking, the behavior of bees, and environmental stewardship opportunities at the park.

\section{Instruments}

Two surveys were used in this study. One, the Ecology and Interdependence Questionnaire (EIQ), was written by this researcher and addressed science content and critical thinking skills related to ecology themes relevant to Tryon Creek State Natural Area. The other survey, the New Ecological Paradigm (NEP) Scale (Dunlap, Van Liere, Mertig, \& Jones, 2000), measured the environmental attitudes of the participants. Structured, individual interviews were administered throughout late summer and fall 2011 after the participants had completed their weeks of working at camp in order to gain 
further insight in the learning and shifts in attitudes and behaviors that occurred over the summer.

Ecology and Interdependence Questionnaire. The following questions were used to assess participants' understanding of forest and riparian ecology in the context of Tryon Creek (see Appendix C for the complete form given to the participants):

1. Name and briefly describe five native plants and/or animals that are found at Tryon Creek State Natural Area.

2. Describe the role that fallen trees and stumps have in a forest ecosystem over time.

3. What role do plants have in stream health and maintaining water quality? 4. Name three invasive plant or animal species that are found in Tryon Creek State Natural Area. For one of these species, please describe its negative impacts on the ecosystem and how it can be managed.

5. Early in the 20th century, wolves in the southwest United States began eating sheep and other livestock from farms and ranches. In response to complaints from ranchers who were losing their livestock, government land managers implemented a hunting program to control the wolf population. Study the following food web diagram [see Appendix C] for the desert ecosystem from the time before settlers moved in and established sheep and cattle ranches. How might the populations of the plants and animals shown in the food web have been impacted as a result of the wolf hunting program? Describe the shifts or changes in the food web that may have occurred on the back of this page. 
These questions were chosen to align with the learning objectives of the training provided to the assistant counselors in the experimental group. These ecology concepts could have been learned through participation in camp, but may not have been explicitly addressed. Question five was included to address critical thinking skills - the participants' ability to relate ecology concepts to dilemmas in a context other than Tryon Creek.

Participants' responses were rated on a scale of 1 to 5 (for a total of 25 points possible) using a mark scheme scoring guide (Appendix D). The scoring guide was created by this researcher in conjunction with a project for a graduate level course in assessment of student achievement in science. An initial draft of the scoring guide was made by listing all desired correct responses for each question. After the summer, completed questionnaires were read through, and additional correct student responses were added to a final draft of the scoring guide.

Validity. In order to determine face validity, the EIQ was shown to three experts in science education as well as several peers studying science education. The science education experts and peers provided feedback and the questionnaire was revised several times taking into account their suggestions. Additionally, a pilot test of the EIQ was conducted on May 13, 2011 with four local high school students in order to determine its construct validity. According to Trochim (2006), construct validity refers to "the degree to which inferences can legitimately be made from the operationalizations in your study to the theoretical constructs on which those operationalizations were based" (Idea of Construct Validity section, para. 1). In other words, an instrument has construct validity if it indeed measures what it sets out to measure, in this case knowledge of ecological 
principles. The four students who pilot tested the EIQ were enrolled in a senior inquiry course at a high school in Portland, Oregon and had varying amounts of previous science coursework, similar to the participants of this study. The students were encouraged to ask clarifying questions, make note of any phrasing in the questions that seemed unclear, and to answer the questions as completely as they were able. Their suggestions and responses were used to clarify the phrasing of the questions. For example, question number five was originally worded:

Early in the 20th century, wolves in the southwest United States began eating sheep and other livestock as their natural prey (deer and other small animals) began to disappear. In response, land managers implemented a hunting program to control the wolf population. Study the following food web diagram. What shifts or changes likely occurred in the desert southwest ecosystem due to the loss of the wolves?

During the pilot test, three of the four students asked whether or not the livestock were considered part of the desert ecosystem and why sheep were not included on the food web diagram (see Appendix C), which depicts the ecosystem before settlement of the ranchers. The question was reworded, clarifying when and why wolves began eating livestock and why the wolf hunting program was implemented. Further, the question was changed to explicitly ask what changes in the native ecosystem (plants and animals present pre-settlement_-grass, rabbits, deer, snakes, owls, and wolves) were likely caused by the wolves being hunted. 
Reliability. Participant responses on the EIQ were scored by a second science educator in order to check the inter-rater reliability of the mark scheme scoring guide. Ten questionnaires (five pretests and five posttests from different individuals) were scored by the second rater and inter-rater reliability was calculated by dividing the number of data points in which both raters agreed by the total number of data points (10 questionnaires $x 5$ questions each $=50$ ). This researcher and the second rater agreed on thirty-two of the questions for an inter-rater reliability of $64 \%$, however the inter-rater reliability for within one point increased to $92 \%$ (the raters disagreed by one point on fourteen questions and by two points on the remaining four questions). After discussion with the second rater, it was determined that this researcher was systematically more accepting of partial or awkwardly worded responses than the second rater, suggesting that although the inter-rater reliability was not high, the intra-rater reliability of this researcher was likely high.

New Ecological Paradigm (NEP) Scale. The New Ecological Paradigm (NEP) Scale was used to measure participants' environmental attitudes pre and post summer camp. This instrument was created by Dunlap et al. (2000) to measure the extent to which respondents have an ecological worldview. The scale consists of 15 items which are adapted and revised from the original 1978 New Environmental Paradigm scale created by Dunlap and Van Liere (1978). The fifteen items in the survey fall under five categories (three items per category): the reality of limits to growth $(1,6,11)$, antianthropocentrism $(2,7,12)$, the fragility of nature's balance $(3,8,13)$, rejection of exemptionalism $(4,9,14)$, and the possibility of an ecocrisis $(5,10,15)$. The odd 
numbered items are worded so that agreement indicates a positive environmental view, whereas the even numbered items are worded so that agreement indicates a negative environmental view. The responses are measured by a 5-point Likert type scale. Both editions of this instrument have been used widely used, including in studies in Pacific Northwest. For information on the validity testing of the instrument, refer to Dunlap et al. (2000). See Appendix E for the form that participants used to fill out the NEP Scale. Individual interviews. Eight participants were interviewed at the conclusion of their camp experience. The follow questions were asked:

1. What is your favorite memory from camp at Tryon Creek?

2. What was your most challenging or frustrating moment at camp?

3. What made you decide to volunteer as an assistant counselor? Have you worked at other camps?

4. What was the most valuable science content that you learned at camp?

5. What was most and least helpful in preparing you to be an assistant counselor?

6. How have your impressions of and feelings toward Tryon Creek State Park changed over the summer?

7. Before you came to camp, did you talk to your friends and family about environmental issues like recycling, conserving natural resources, and climate change? Why or why not? Do you talk about these things more now that you have been to camp? 
8. Sometimes kids are allowed to play in Tryon Creek. Do you think that is a good idea? Why or why not? Would you have answered the same way before this summer?

9. Before you came to camp were you interested in visiting or working at other state and national parks? Has your level of interest changed over the summer?

10. Is there something that you might do differently in the future as a result of your experience here? (i.e. daily habits, working with kids, sustainable life choices)

11. Would you call yourself an environmentalist? Why or why not? (In your opinion, what is an environmentalist?)

The participants' responses were audio recorded and transcribed for analysis (see Appendix F for copies of interview transcripts). The interview questions were reviewed and modified with three science education experts and several peers studying science education in order to determine their face validity.

\section{Data Analysis}

Survey and interview data were tabulated and manipulated in Microsoft Excel. All statistical analyses were performed using Minitab.

Ecology and Interdependence Questionnaire. Pre and posttest scores on the EIQ were compared between all participants $(n=22)$ using a Two-Sample $t$-Test to see if ecology content knowledge gains were made over the summer. Separate Two-Sample $t$ Test were also run comparing the pre and post scores of each of the five questions in the EIQ in order to determine which content areas showed the most improvement. 
Additionally, a Two-Sample $t$-Test was used to compare improvement from pre to posttest scores between the experimental $(n=4)$ and the control group $(n=18)$ to see if the experimental group showed greater knowledge gains over the summer than the control group.

New Ecological Paradigm Scale. NEP Scale responses were tallied into an Excel spreadsheet, noting how many of the participants answered strongly agree, agree, unsure, disagree, or strongly disagree for each item. Separate tables were made for pre and posttests as well as for the experimental and control groups. Once the responses were tallied, the data was arranged from a strong positive environmental orientation to a strong negative environmental orientation when reading left to right across the spreadsheet.

An expert in statistics was consulted on how to analyze NEP Scale data. Tallied data was weighted in order to create a total score for each of the fifteen items. The strong positive responses were multiplied by 9 , the mildly positive responses were multiplied by 3 , the unsure responses were multiplied by 1 , the mildly negative responses were multiplied by -3 , and the strongly negative responses were multiplied by -9 . Finally, these weighted values were added together so that each question had a score that reflected the groups' environmental attitude orientation. Positive values indicated a positive environmental response, negative values indicated a negative environmental response, and values close to zero represented a neutral response.

A Two-Sample $t$-Test was used to compare the pre and posttest weighted scores for all participants $(n=22)$ to see if the groups' environmental attitudes improved over the summer. The difference between weighted posttest and pretest scores were also 
compared between the experimental $(n=4)$ and the control group $(n=18)$ using a TwoSample $t$-Test in order to see if the experimental group showed more strongly improved environmental attitudes than the control group. Finally, a one-way ANOVA was used to compare the improvement from pre to post scores for all participants between the five different categories (limits to growth, antianthropocentrism, etc.) in order to see if environmental attitudes changed in certain categories more than others.

Interviews and training journals. Common themes were pulled from interview transcripts using a method inspired by grounded theory (Glaser \& Strauss, 1967), and the themes were organized in according to how they related to the research question of the study. Main points of interest were participant comments relating to science that they learned, indication of their attitudes and behaviors toward the environment, their leadership style with children, and their sense of connection to Tryon Creek State Natural Area and the outdoors in general. The training journals were assessed by searching for participant comments that reflected ecological content knowledge and a strong sense of place at the park. 


\section{Results}

The results are organized in three main sections relating to participants' gains in: 1) ecology content knowledge, 2) environmental stewardship attitudes and behaviors, and 3) ability to be a positive leader for young people in an outdoor setting. Within each section, survey results are presented first, followed by interview and training journal findings. As participants are quoted from their interviews, their grouping (experimental or control) is noted following their name. Major emergent interview themes did not vary greatly between the experimental and control groups, but by triangulating the survey, interview, and journal data, conclusions can be made about what participants of the training gained from their unique experience. Outcomes from participation in the training program are presented within each section.

\section{Ecology Content Knowledge}

Ecology and Interdependence Questionnaire findings. A statistically

significant difference was found (see Table 4 and Figure 1) when comparing pre and posttest scores on the Ecology and Interdependence Questionnaire for all participants of

\section{Table 4}

Comparison of EIQ Pre and Posttest Scores of All Participants

\begin{tabular}{|l|c|c|c|c|c|}
\hline Test & $n$ & $M$ & $S D$ & $p$ & $95 \%$ CI \\
\cline { 1 - 4 } Pretest & 22 & 13.50 & 5.12 & \multirow{2}{*}{$\mathbf{0 . 0 3 7} *$} & $-5.64,-0.18$ \\
\cline { 1 - 4 } Posttest & 22 & 16.41 & 3.71 & & \\
\cline { 1 - 4 } & & &
\end{tabular}

Note. A Two-Sample $t$-Test was used. CI = confidence interval. A total of 25 points were possible on the EIQ (Ecology and Interdependence Questionnaire).

$* p<.05$ indicating a statistically significant difference between pre and posttest scores at a $95 \%$ confidence level. 


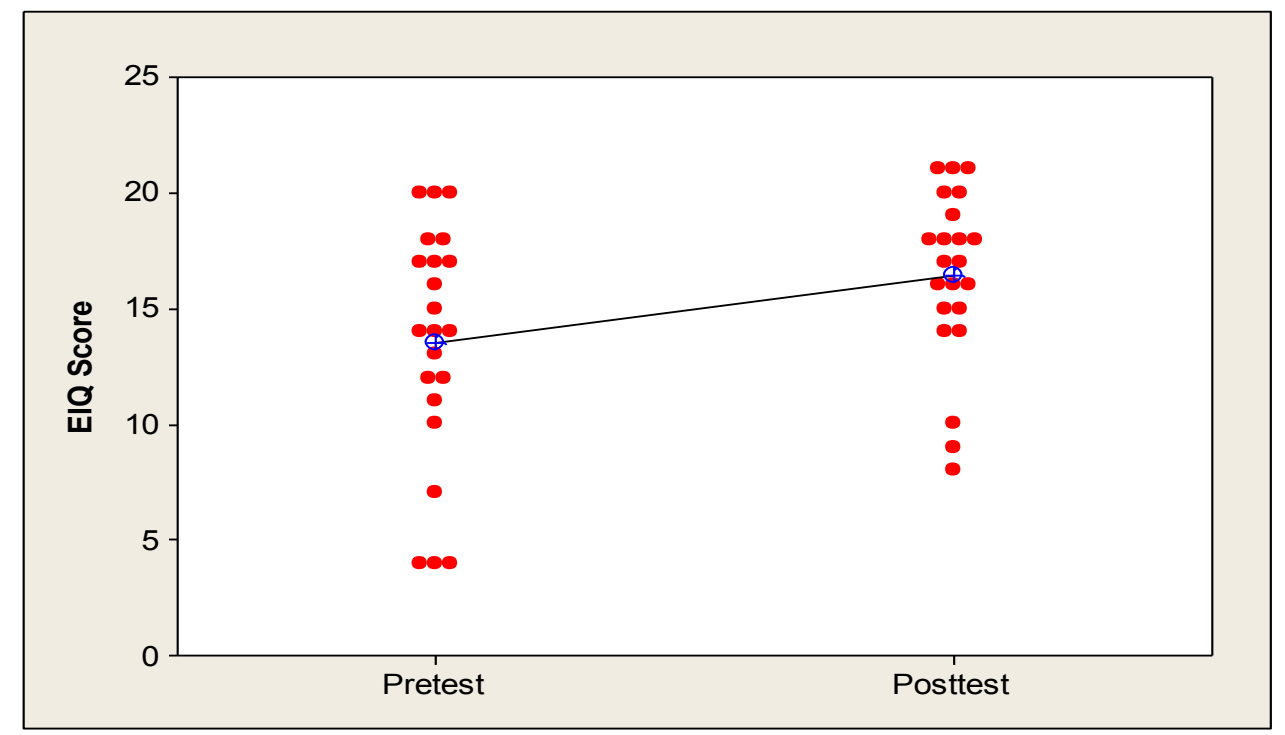

Figure 1. Ecology and Interdependence Questionnaire (EIQ) Scores. This figure displays EIQ scores for all participants. The line shows the increase in the mean score from pre to posttest $(p=0.037)$.

the study. The highest scores received (out of 25 possible points) were 20 and 21 points for the pre and posttests, respectively. The lowest pretest score was 4 and the lowest score on the posttest was 8 . Participants did relatively well (an average of 4.5 out of 5 points on the posttest) on the first question which was about native plants and animals found at Tryon Creek State Natural Area. Questions two and three seemed to be the most challenging for participants (mean scores on the posttest were 2.86 and 1.95). These were short answer questions about the function of nurse logs in a forest and the role of plants in stream health. Participants typically listed just one or two ideas-it was unclear whether or not they could have given more complete answers. Answers were generally more thorough on the other three questions. Scores were most improved from pre to posttest on question number four (see Figure 2).

The statistically significant difference in mean pre and posttest scores was attributed to improvement on question number four which dealt with knowledge of 


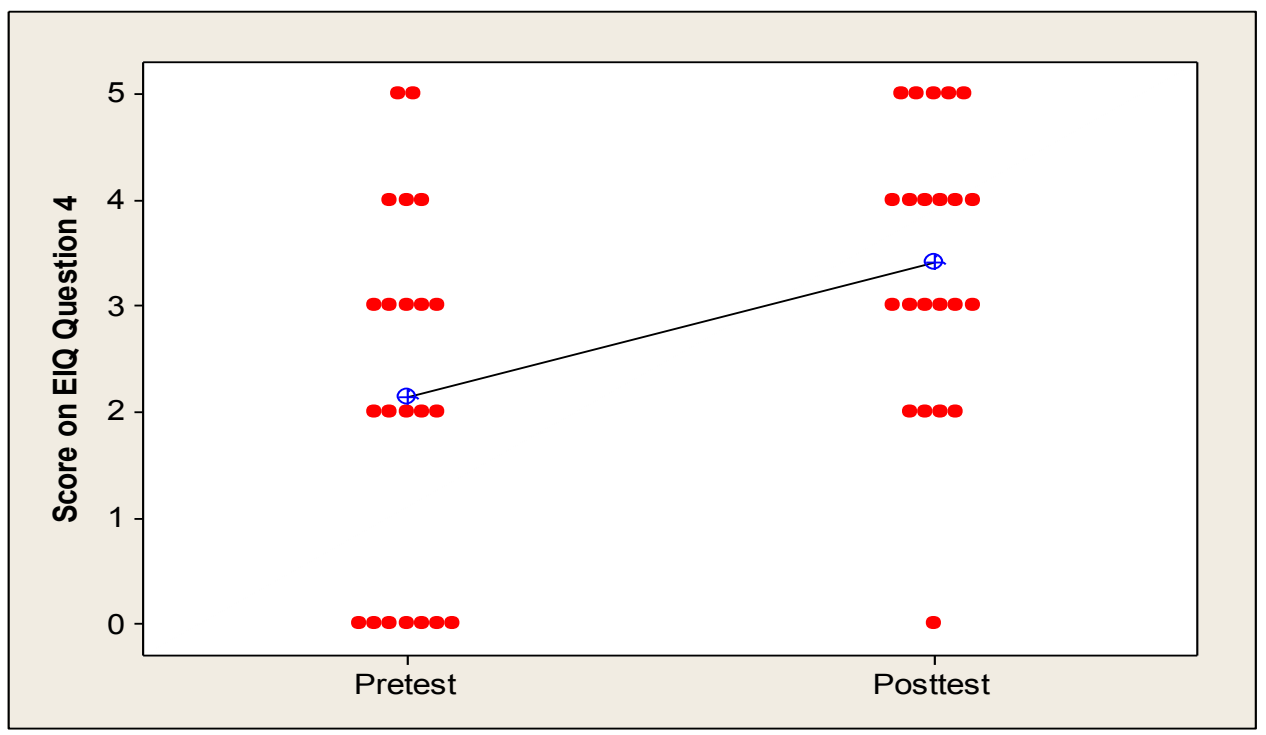

Figure 2. Ecology and Interdependence Questionnaire (EIQ) Scores on Question 4. This figure displays EIQ scores on question 4 for all participants. The line shows the increase in the mean score on question 4 from pre to posttest $(p=0.009)$.

invasive species present in Tryon Creek State Natural Area. Although the mean scores for all five questions increased from the pretest to the posttest, only question four showed a statistically significant difference (see Table 5 for the Two-Sample $t$-Test results comparing pre and post scores for all five questions on the EIQ).

\begin{tabular}{|c|c|c|c|c|c|c|}
\hline \multicolumn{7}{|c|}{$\begin{array}{l}\text { Table } 5 \\
\text { Comparison of EIQ }\end{array}$} \\
\hline Question & $M$ - pre & $M$ - post & $S D$ - pre & $S D$ - post & $p$ & $95 \% \mathrm{CI}$ \\
\hline 1 & 4.05 & 4.50 & 1.05 & 1.06 & 0.159 & $-1.10,0.19$ \\
\hline 2 & 2.68 & 2.86 & 1.00 & 0.83 & 0.515 & $-0.74,0.38$ \\
\hline 3 & 1.68 & 1.95 & 0.95 & 1.05 & 0.369 & $-0.88,0.33$ \\
\hline 4 & 2.14 & 3.41 & 1.73 & 1.30 & 0.009* & $-2.21,-0.34$ \\
\hline 5 & 2.95 & 3.68 & 2.08 & 1.32 & 0.175 & $-1.80,0.34$ \\
\hline
\end{tabular}


Another Two-Sample $t$-Test was used to compare improvement (posttest score pretest score) between the experimental and control groups in order to determine whether the experimental group made greater ecology content knowledge gains over the summer than the control group due to participation in the training program. No statistically significant difference was found $(p$-value $=0.564)$. Table 6 shows the pre and posttest scores of the four participants in the experimental group. See Appendix G (Table 10) for the EIQ scores of all participants in the control group. Three of the four participants in Table 6 EIQ Scores for the Experimental Group

\begin{tabular}{|l|c|c|c|c|}
\hline Name & Pretest score & Posttest score & Improvement & Posttest date* \\
\hline Celia & 4 & 9 & 5 & Oct 10, 2011 \\
\hline Hazel & 18 & 18 & 0 & Aug 26, 2011 \\
\hline Owen & 16 & 17 & 1 & fall 2011** \\
\hline Zoe & 18 & 21 & 3 & Aug 5, 2011 \\
\hline $\begin{array}{l}\text { Note. Maximum points possible }=25 . \\
\text { *All pretests were taken on June 24, 2011 at the beginning of training. } \\
\text { **OWwen was emailed the posttest in August (per his request), but forgot to return it until November } \\
\text { when he met for an interview. It was unclear when he filled it out between August and November. }\end{array}$ \\
\hline
\end{tabular}

the experimental group (Hazel, Owen, and Zoe) came into the training with a fair amount of prior knowledge about the ecology of western Oregon, indicating a possible ceiling effect. In the control group, many participants did well on the pretest, but only 7 out of 18 participants scored 15 points or more, compared to 3 out of 4 in the experimental group. Due to time constraints at camp, Owen and Celia were unable to fill out their posttests until the fall. These circumstances (significant prior knowledge and elapsed time before taking the posttest) may help explain why more significant gains in posttest scores were 
not seen in the experimental group. Additionally, Celia (who received low scores on the EIQ) mentioned during training and in her interview that she was more interested in learning about the history of the park than the ecology.

Interview findings. Interview responses corroborate the findings from the Ecology and Interdependence Questionnaire. When the eight interviewees were asked, "What was the most valuable science content that you learned at camp?" half (two experimental and two control group interviewees) mentioned that they enjoyed seeing and/or learning about the different plants and animals found at the park. Participants generally did quite well on EIQ question one which dealt with naming and describing native species of the park. Many participants were returning assistant counselors or had been exposed to environmental education in another context and were eager to continue learning about western Oregon's natural history. Liza (control group) stated that, "The most valuable thing would be learning how to identify plants better, especially things like stinging nettle and plants that you don't want to touch...also plants that can be useful." Liza's sister Kate (control group) mentioned that she really enjoyed seeing wildlife at the park, especially birds. She related that one day, "just as we were starting our hike, I thought I glimpsed a pileated [woodpecker] which is always really cool. And then...a little ways along the trail we spotted a great horned owl."

Two interviewees reported that learning about invasive species was the most "informative" (Owen - experimental group) and "interesting" (Josh - control group) in terms of science concepts learned at camp. Josh was surprised at how pervasive English ivy is at the park and around Oregon and expressed that, 
Other species...come here and...take over native plants. It's interesting to see...I was driving on Barbur [Blvd.] the other day and every single tree along there is covered in ivy...It doesn't seem like there will be a way to get rid of it anytime soon because it spreads so vastly. Walking around here [Tryon Creek State Natural Area] I know they've done a really good job [removing English ivy]...but there's so much of it and...it's taken over a lot of the forests around here and everywhere.

Like Josh and Owen, many assistant counselors were likely struck by how pervasive plants like English ivy, Himalayan blackberry, and English holly are in Tryon Creek State Natural Area. The awe that Josh expressed toward how widespread invasive species are may shed light on why participants' scores improved over the summer on the question relating to invasive species on the EIQ.

A couple other ecology concepts were brought up when interviewees were asked what science concepts learned over the summer were the most valuable to them. Zoe (experimental group) found the concept of interdependence within forest ecosystems (the main focus of the training program) important for her own learning as well as teaching. She explained that, "The ecology where if one animal or plant is eliminated how it affects the entire forest or ecosystem... It's really interesting and that was one of the main points that I wanted to teach the kids that we had here." Learning about stream ecology and water quality monitoring was most memorable for Adam (control group) who recalled during his interview that, "The perfect stream is a $\mathrm{pH}$ of 7 and dissolved oxygen and parts per million of around 8 to 10." Hazel (experimental group), who had previously worked 
as an Outdoor School student leader, was most impressed by how excited her young campers were to learn about the forest.

Training program learning assessment. Celia, Hazel, Owen, and Zoe expressed that they learned a great deal during the ecology training program. In their interviews, journals, and conversations, they emphasized their increased knowledge of local flora, interdependence within the forest ecosystem, and the history of Tryon Creek. The training program allowed participants to explore these topics in depth, perhaps more so than during summer camp. Celia reported in her interview, "I learned more from your training than being an aide [assistant counselor].” Zoe concluded her interview by relaying how beneficial the training was for her: "The overnight...training was really good. That was a lot of fun...I think doing that in future years would be good...I definitely learned a lot from that. A lot."

What participants learned. At the end of the training program, participants completed a self-assessment of their learning over the weekend (see the training journal in Appendix A for the form used). Participants assessed their knowledge and skills on specific topics covered during the training on a scale of 1 to 6 , with 1 being novice, 4 being proficient, and 6 being expert. In terms of the learning objective, "I can describe living and non-living components of an ecosystem and explain how those components are interconnected," Hazel, Owen, and Zoe rated themselves as a 5 or 6 in all four categories (describing and classifying organisms, interactions in forest ecosystems, drawing food webs, and diagramming nutrient cycles). Celia scored herself as a 4 or 5 in all categories. All participants felt proficient, if not expert in the aforementioned topics at the conclusion 
of the training. The participants certainly demonstrated their proficiency by the responses throughout their journals — their food web diagrams were detailed and accurate, their definitions of interdependence were thoughtful, and they gave expert assessments of the environmental sustainability concerns of the park.

In the self-assessment, participants also listed some of the most interesting things that they learned about the ecology of the Tryon Creek forest during training. The concept of interdependence was indeed important to the participants. Zoe recorded that she learned "a lot more in depth about how important every organism is in each ecosystem." Celia was interested in "how everything works together" in the forest. Hazel acknowledged that she "never knew just how significant each species is to the ecosystem as a whole." Participants also reported that the following concepts would be most useful for teaching their campers over the summer:

- "Sustainability and relations between many organisms." - Owen

- "Learning names of plants and animals who live here and some history of Tryon." - Celia

- "Biodiversity, Interdependence." - Hazel

- "How important every organism is in each ecosystem and the different types of plants and animals." - Zoe

The above responses are consistent with comments from their interviews about what was most helpful in their training to be an assistant counselor and what they taught campers over the summer. The training program seems to have been influential in participants' learning and teaching of ecology, history, and sustainability over the summer. 
What participants did not learn. At the end of the training, participants were asked to record in their journals what questions they still had about the ecology of the forest. Owen was still curious about "what endangered species live in Tryon Creek," and Hazel reported that she would like to learn more about "the animals and how we learn about them." Hazel also mentioned that she wanted "to learn more about the streams," and similarly, Zoe wanted "to know more about the creek and why there aren't as many fish as...environmentalists would like there to be." Celia did not record any final questions about ecology in her training journal.

In summary, the participants did not learn as much about animals and stream ecology as other topics presented during the training. EIQ posttest data corroborates this assessment. All four participants named more plants than animals on the EIQ question about native species of the park. Additionally, Celia, Hazel, and Owen scored the lowest on the question about the role of plants in stream health, with Celia receiving zero points on this question. Zoe gave a more complete answer than the others, but scored higher on three of the other questions on the EIQ. In future trainings, more emphasis should be placed on stream ecology and the fauna of the park. Recommendations for how to improve future training programs are presented in greater detail in the Discussion section.

\section{Environmental Stewardship Attitudes and Behaviors}

New Ecological Paradigm Scale Results. On fourteen of the fifteen items on the New Ecological Paradigm (NEP) Scale, participants had an overall positive environmental viewpoint or ecological worldview (see Table 7). The only item for which 


\begin{tabular}{|c|c|c|c|c|}
\hline $\begin{array}{l}\text { Table } 7 \\
\text { New Ecological Paradigm Scale: Relative }\end{array}$ & Environmen & Attitud & & \\
\hline Category/Item & $\begin{array}{l}\text { Ecological } \\
\text { worldview* }\end{array}$ & $\begin{array}{c}\text { Pretest } \\
\text { total }\end{array}$ & $\begin{array}{c}\text { Posttest } \\
\text { total }\end{array}$ & $\begin{array}{l}\text { Change: } \\
\text { Post - Pre }\end{array}$ \\
\hline The reality of limits to growth & & 48 & 128 & 80 \\
\hline $\begin{array}{l}\text { We are approaching the limit of the number of } \\
\text { people the earth can support. }\end{array}$ & Agree & 94 & 82 & -12 \\
\hline $\begin{array}{l}\text { The earth has plenty of natural resources if we } \\
\text { just learn how to develop them. }\end{array}$ & Disagree & -82 & -47 & 35 \\
\hline $\begin{array}{l}\text { The earth is like a spaceship with very limited } \\
\text { room and resources. }\end{array}$ & Agree & 36 & 93 & 57 \\
\hline Antianthropocentrism & & 352 & 362 & 10 \\
\hline $\begin{array}{l}\text { Humans have the right to modify the natural } \\
\text { environment to suit their needs. }\end{array}$ & Disagree & 60 & 56 & -4 \\
\hline $\begin{array}{l}\text { Plants and animals have as much right as humans } \\
\text { to exist.** }\end{array}$ & Agree & 180 & 168 & -12 \\
\hline $\begin{array}{l}\text { Humans were meant to rule over the rest of } \\
\text { nature. }\end{array}$ & Disagree & 112 & 138 & 26 \\
\hline The fragility of nature's balance & & 280 & 320 & 40 \\
\hline $\begin{array}{l}\text { When humans interfere with nature it often } \\
\text { produces disastrous consequences. }\end{array}$ & Agree & 112 & 98 & -14 \\
\hline $\begin{array}{l}\text { The balance of nature is strong enough to cope } \\
\text { with the impacts of modern industrial nations. }\end{array}$ & Disagree & 70 & 120 & 50 \\
\hline $\begin{array}{l}\text { The balance of nature is very delicate and easily } \\
\text { upset. }\end{array}$ & Agree & 98 & 102 & 4 \\
\hline Rejection of exemptionalism & & 199 & 258 & 59 \\
\hline $\begin{array}{l}\text { Human ingenuity will insure that we do NOT } \\
\text { make the earth unlivable. }\end{array}$ & Disagree & 29 & 34 & 5 \\
\hline $\begin{array}{l}\text { Despite our special abilities humans are still } \\
\text { subject to the laws of nature.** }\end{array}$ & Agree & 120 & 146 & 26 \\
\hline $\begin{array}{l}\text { Humans will eventually learn enough about how } \\
\text { nature works to be able to control it. }\end{array}$ & Disagree & 50 & 78 & 28 \\
\hline The possibility of an ecocrisis & & 356 & 408 & 52 \\
\hline Humans are severely abusing the environment. $* *$ & Agree & 112 & 154 & 42 \\
\hline $\begin{array}{l}\text { The so-called "ecological crisis" facing } \\
\text { humankind has been greatly exaggerated. }\end{array}$ & Disagree & 98 & 128 & 30 \\
\hline $\begin{array}{l}\text { If things continue on their present course, we will } \\
\text { soon experience a major ecological catastrophe. }\end{array}$ & Agree & 146 & 126 & -20 \\
\hline $\begin{array}{l}\text { Note. The values scale is from } 198 \text { to }-198 \text { for indi } \\
\text { strong agreement or disagreement). The scale is } 59 \\
\text { category x } 198 \text { and }-198 \text { ). Values close to zero sigr } \\
\text { scale indicate a positive environmental attitude, an } \\
\text { environmental attitude. See the Method section for } \\
\text { for each item were calculated. } \\
* \text { Response reflecting a positive environmental attit } \\
\text { creators of this instrument (Dunlap et al., 2000). } \\
* * \text { Participants showed the strongest positive envir }\end{array}$ & $\begin{array}{l}\text { dual items (2) } \\
\text { to }-594 \text { for th } \\
\text { fy a neutral vi } \\
\text { low negative } \\
\text { detailed desc } \\
\text { de, or an "eco }\end{array}$ & $\begin{array}{l}\text { point, hig } \\
\text { ues indic } \\
\text { tion of ho } \\
\text { ical worl }\end{array}$ & $\begin{array}{l}\text { ew," acc } \\
\text { a negati } \\
\text { the weig }\end{array}$ & $\begin{array}{l}\text { ghting for } \\
\text { ons per } \\
\text { ues on the } \\
\text { ding totals }\end{array}$ \\
\hline
\end{tabular}


participants as a whole had a negative environmental view was: "The earth has plenty of natural resources if we just learn how to develop them." It should be reiterated that values in Table 7 are weighted tallies for the entire participant group $(n=22)$ and do not reflect exactly how each individual responded — the weighted tallies are meant to provide a snapshot of how the group as a whole leaned in terms of their environmental attitude. The three items on the posttest where participants showed the strongest agreement (and positive environmental attitude toward) were: "Plants and animals have as much right as humans to exist," "Humans are severely abusing the environment," and "Despite our special abilities humans are still subject to the laws of nature."

There were no statistically significant differences between pre and post scores on the NEP Scale, nor were there differences between the experimental and control group. Pre and posttest weighted tallies for each item on the NEP Scale were compared using a Two-Sample $t$-Test (for the entire group of participants). No statistically significant difference was found ( $p=0.453$, see Table 8). A One-way ANOVA was also performed in order to see if changes from pre to posttest (far right column in Table 7) were greater in any of the five overarching categories than others. No statistically significant difference was found between the means of the five categories $(p=0.885)$. Lastly, Table 8 Comparison of NEP Scale Pre and Posttest Weighted Totals for All Participants

\begin{tabular}{|l|c|c|c|c|c|}
\hline Test & $n^{*}$ & $M$ & $S D$ & $p$ & $95 \% \mathrm{CI}$ \\
\hline Pretest & 15 & 82.3 & 60.9 & \multirow{2}{*}{0.453} & \multirow{2}{*}{$-59.4,27.3$} \\
\cline { 1 - 4 } Posttest & 15 & 98.4 & 54.6 & & \\
\hline
\end{tabular}


change (post - pretest weighted totals $/ n)$ in experimental $(n=4)$ and control $(n=18)$ groups was compared by doing a Two-Sample $t$-Test. No statistically significant difference was found $(p=0.775)$.

The lack of significant improvement in environmental attitudes as measured by the NEP Scale could be due to many factors:

Firstly, the assistant counselors who volunteer to work at camp tend to already have somewhat positive environmental attitudes (ceiling effect). Pretest scores on the NEP Scale showed that the participants did begin the summer with an overall positive attitude toward the environment. Many assistant counselors come from families that have positive environmental attitudes and behaviors. For example, seven of the eight interviewees specifically mentioned that their families are environmentally conscious (i.e. they recycle, compost, conserve electricity, buy eco-friendly household products, and/or hike together), and two of the eight interviewees reported that they have been interested in environmental issues since early childhood. Owen (experimental group) revealed during his interview that, "I come from a family that recycles and composts everything." Similarly, Adam (control group) described his family by stating that, "we're pretty conservative with how we live." Finally, Hazel (experimental group) recalled that "I was interested in most of those things [environmental issues - see interview question four] ever since I was pretty little, especially recycling."

Secondly, the items on the NEP Scale vary in their extremity-some items are obviously positive or negative, others are more ambiguous. Participants' responses on the NEP Scale reflect optimism for human ingenuity, even on some items where overall, 
participants did not have an "ecological worldview." For example, the only item for which participants had a negative environmental attitude on both the pre and posttest was: "The earth has plenty of natural resources if we just learn how to develop them." According to Dunlap et al. (2000), agreement with the preceding statement indicated a negative environmental viewpoint. Participants did generally agree with the statement, but it is possible that their belief in Earth's plentiful resources could be due to the rise in popularity of alternative fuels and more sustainable harvest practices, rather than a vision of clear cutting every forest or strip mining every mountain. Additionally, the two items for which participants had the greatest shift toward a more negative environmental view could be due to increased optimism in human efforts to care for the environment. The two items were: "When humans interfere with nature it often produces disastrous consequences," and "If things continue on their present course, we will soon experience a major ecological catastrophe." Perhaps after seeing how active the stream restoration, invasive species removal, and environmental education volunteers are at Tryon Creek State Natural Area, the participants of this study did not have such a fatalistic attitude about what humans are doing to the environment. Josh (control group) reflected this sentiment in his interview, stating that "There's a really good community around here [Tryon]...people are really trying to change things... and I'm really glad there's a camp here to let kids know about different environmental issues."

Sense of place. A major theme that emerged during interviews which related to positive attitudes toward the environment was the connection that participants made with Tryon Creek State Natural Area and the outdoors in general. Interviewees were asked 
how their impression of and feelings toward the park had changed over the summer. The following excerpts illustrate the connection that participants developed with the park and how well they got to know the area:

- 'I know it [Tryon Creek State Natural Area] better...It's not just something you pass every day...It's become a part of my life." - Celia (experimental group)

- "In the beginning it was just another state park... just [an] industrialized part of Lake Oswego, but when we got farther in I saw that they had a considerable amount of species that treated it as home, and how it was a very old forest." Owen (experimental group)

- “After doing camp for a couple years, it's expanded what I've known of Tryon Creek." - Adam (control group)

- "It was nice to be in the woods for multiple hours every day. It was a really cool experience to be walking around in all those beautiful trees with a group of mostly happy kids." - Kate (control group)

- “I think it's a pretty amazing place.” - Hazel (experimental group) Additionally, many interviewees acknowledged the importance of outdoor play and developing affection for nature at a young age in order to develop respect and stewardship for the environment. When asked, "Sometimes kids are allowed to play in Tryon Creek. Do you think that is a good idea?" five interviewees (three experimental and two control group participants) responded yes because playing outside was important for kids in order to develop love and respect for nature. Zoe (experimental group) explained that, "If they grow up not being able to play in nature, they probably won't 
have as much respect or love towards it." Similarly, Liza (control group) said that, "It's good to teach kids about conserving nature. If they have fun out in the woods and if they want to keep having fun they need to...help conserve it.” Owen (experimental group) emphasized that "It's really good to have kids get outdoors, especially in the summer, with all the technology...the exercise and knowledge that they've been gaining out there is a really important part of Tryon Creek." Three interviewees (one experimental and two control group participants) did not think that kids should play in the creek, but they agreed that it was very important for the kids at camp to learn why we need to protect fragile streamside areas. Josh (control group) asserted that "If the kids learn that it's okay to do at camp, then they're going to bring that state of mind everywhere else they go."

Connecting to place during the training program. The training program provided several opportunities for participants to connect to a sense of place. The participants had two half hour time blocks to be by themselves on the trail and explore place through a chosen lens such as: artistic, historical, scientific, literary, transcendental, or experiential. A nature yoga class was also taught on the last morning of the training and the participants wrote in their journals about the experience.

Celia, Hazel, and Zoe chose to explore place through an artistic lens for one of the sessions. They sketched intricate drawings of plants and made leaf rubbings of maples and ferns, taking care to label each plant. Celia explored a nurse log during her second session — she made rubbings of sword fern spores, drew a diagram of a nurse log complete with plants, insects, and fungi, and noted that, "this nurse log is a home to many 
plants and animals. It gives them somewhere to live and to grow." Zoe commented next to her artwork that:

It was very peaceful during our half hour time to ourselves in the forest. I felt like I wasn't rushed and could notice all the detail on the leaves and plants around the trail. Most of the time when I hike I don't have enough time.

All participants voiced a similar sentiment after the sessions - that they were amazed with how much they noticed when they were able to take their time.

Owen explored place through historical and transcendental lenses, writing thoughtful reflections during each session. He first commented on the sights and sounds of forest, then noticed evidence of logging and surmised that "it's clear the loggers did not have an appreciation of the natural beauty of Tryon." Owen brought along a history book and found that "most likely the Clackamas or Cowlitz Indians who spoke Chinookan" passed through Tryon, and that "these Indians were probably... moved to Warm Springs Reservation.” Perhaps as a way to step outside of his comfort zone, Owen chose to explore the transcendental aspects of place for the second session. He commented that "as an atheist this is going to be new." Despite this opening line in his journal entry, Owen wrote a passionate reflection:

I see so much beauty. Plants growing intricately in wild patterns, exercising flexibility to rival a snake. They twist upwards clawing for just a sacred patch of golden sun. I feel there must be a force behind it, whether a single omnipotent God pulling a thousand intricate invisible strings or a spirit for every small process and miniscule organism. I do not know. It could very well be codes 
embedded in DNA. What I am sure of though is that this forest operates in ways too beautiful for simple human senses.

It was clear from Owen and the other participants' reflections that they admired the beauty of the forest and felt a strong connection to place.

All of the participants reported similar sentiments about the nature yoga classthat it was enjoyable and relaxing to practice outdoors. Celia found it "more relaxing than it would be...inside," and she "liked hearing the birds and the wind in the trees." Zoe, who had practiced yoga at studios before, noted that "it felt a lot different from other times I have done it before," because indoors "it felt like...forced relaxation... but outside, with the birds singing and the natural light, it felt a lot more natural and I enjoyed it more." Based on all of their journal entries, it seems that nature yoga was a successful way to help participants connect to the forest.

New behaviors and interests. Interviewees were asked if they talk about environmental issues with their friends and family and whether they do so more now that they have worked at a nature camp. Seven of the eight interviewees reported that their families were already environmentally conscious and that they would discuss environmental issues, or that "living green" was a part of their everyday life. Five interviewees (four experimental and one control group participant) mentioned that after camp they discuss environmental issues more with friends or family, and three of those five (all from the experimental group) felt more knowledgeable and confident about discussing environmental issues when they were brought up in conversation. Zoe (experimental group) talked about how her family began composting and using more 
earth-friendly household products during the summer she was at camp. She related the new behaviors of her family to a memorable experience at the ecology training program: When we were doing the overnight camp I saw how with every meal we had, we put something in the recycling bin, or the compost bin with all the worms. And that was kind of cool because when we make our meals, we don't really think about exactly what's going to be going to waste. It was kind of cool to see how you [this researcher] made food cause it was so...healthy for you and it was really good for the environment.

Liza (control group) reported that she was discussing environmental issues more with her friends, whereas her sister Kate (control group) described their family dynamic, stating that environmentally friendly behaviors are "part of what we do at home, so it's not really something we talk about all the time."

When asked whether they would change any daily habits to be more environmentally friendly because of their experience at camp, three interviewees (all from the experimental group) mentioned that that they did feel a greater sense of respect toward the environment and greater awareness of the impacts of the their actions. Two interviewees mentioned specific behaviors they had changed since camp: Owen (experimental group) said he wanted to pick up more trash and Zoe (experimental group) said that she had begun unplugging unused appliances to save energy and that she was now spending more time outside. Hazel (experimental group) and Josh (control group) found that their time in nature made them eager to keep learning. Hazel reported that she wants to continue "Learning more about natural areas and ways to take care of them," 
and Josh eloquently stated that "Being out in the wilderness...the more time you spend, you just become more aware of what you already know.”

Self image as an environmentalist. Participants were asked in their interview whether they would call themselves an environmentalist. All eight interviewees were reluctant to call themselves an environmentalist — seven of the eight said that they were "sort of," "mild," or "it depends," when it came to being an environmentalist. Although Hazel (experimental group) considered herself a person "that cares about and wants to protect the environment," she added the disclaimer that, "I don't know if I would go around being like, 'Hey, I'm an environmentalist!' all the time... It seems a little bit...odd." Others related this same discomfort with the title "environmentalist" even if they considered their values and behaviors to be environmentally conscious. A few other interviewees seemed reluctant to call themselves an environmentalist because they did not think they had the proper qualifications or experience, such as being an activist with an organization or having a college degree in environmental studies. Owen (experimental group) was the only person who directly said he was not an environmentalist, reasoning that, "while I do recycle and compost and pick up trash when I see it, I don't actively try to get the message out there." He believed that his behaviors did not warrant the title of environmentalist because he did not "proactively...advocate for the environment."

The interviewees were also asked to give their definition of an environmentalist. Table 9 displays the main themes that emerged as interviewees described an environmentalist, as well as representative quotes for each theme. Some participants mentioned more than one theme in their definition. 


\begin{tabular}{|c|c|c|}
\hline \multicolumn{3}{|c|}{$\begin{array}{l}\text { Table } 9 \\
\text { How Participants Define an Environmentalist }(n=8)\end{array}$} \\
\hline Theme & Supporting ideas & Representative quotes \\
\hline Stewardship & $\begin{array}{l}\text { Caretaker and } \\
\text { protector of } \\
\text { environment } \\
\text { Considers wellbeing } \\
\text { of natural world over } \\
\text { economic gain } \bullet \\
\text { Awareness of human } \\
\text { impacts to the } \\
\text { environment }\end{array}$ & $\begin{array}{l}\text { An environmental steward... Someone that is actively involved } \\
\text { in caring for and learning more about the environment. }- \text { Hazel } \\
\text { - Anyone who thinks about what they do and how if affects the } \\
\text { world around them, and tries to make changes that will support } \\
\text { the world around them. }- \text { Kate } \bullet \text { Someone who puts the } \\
\text { wellbeing of a forest or a natural environment before gain that } \\
\text { could be taken from harming the forest. - Adam } \bullet \text { Someone } \\
\text { who pays attention to what's going on with the environment } \\
\text { and how what we're doing... affects it...it is like } \\
\text { stewardship... being respectful to it. - Zoe }\end{array}$ \\
\hline Knowledge & $\begin{array}{l}\text { Has studied the } \\
\text { natural world } \bullet \text { Has } \\
\text { degree in } \\
\text { environmental field • } \\
\text { Continually learning } \\
\text { • Educates others }\end{array}$ & $\begin{array}{c}\text { You've probably...gone through college and gotten your } \\
\text { degree in something environmental based, but I think people } \\
\text { that care a lot about the environment could also be considered } \\
\text { environmentalists. - Josh } \bullet \text { Someone who has knowledge about } \\
\text { the environment... and they can educate others. - Celia } \\
\text { People who teach other people how to respect and help the } \\
\text { environment. - Zoe }\end{array}$ \\
\hline Activism & $\begin{array}{l}\text { An advocate } \cdot \text { Gets } \\
\text { the message out to } \\
\text { people } \cdot \text { Works with } \\
\text { environmental } \\
\text { organizations }\end{array}$ & $\begin{array}{l}\text { Someone who proactively tries to advocate for the environment } \\
\text { in ways that goes beyond your standard life. - Owen - } \\
\text { Someone who cares a lot about the environment and is } \\
\text { involved in ways to help conserve it and to help inform other } \\
\text { people about the issues that are going on and ways that they } \\
\text { can help. - Liza }\end{array}$ \\
\hline
\end{tabular}

\section{Leadership and Role Modeling Environmental Stewardship}

Over the summer, assistant counselors gained experience working with kids:

managing challenging behavior, keeping kids engaged in activities, and teaching kids

about the environment. All eight interviewees reported that their favorite memory of

camp related to working with the campers. Interviewees mentioned that they enjoyed

being in a leadership role and having kids look up to them, sharing fun one-on-one

conversations with campers, playing games at special places in the park like the

suspension bridge or the "elephant" tree, and sharing their enthusiasm for wildlife and

nature with the kids. Notably, all interviewees also mentioned that managing challenging 
camper behavior, keeping their group together on the trail, and dealing with tough situations were the most frustrating experiences they had at camp. Participants certainly learned from these challenging experiences with their campers-interviewees expressed interest in continuing to work with kids and four (one from the experimental group and three from the control) specifically mentioned that they felt more knowledgeable and prepared to deal with large groups and/or challenging situations with kids.

Many interviewees relayed that they were more interested in working with kids or that they already were working with kids again, and perhaps incorporating new behaviors that they learned through their assistant counseling experience. Zoe (experimental group), as mentioned earlier in the results section, found that learning about interdependence during the training program was important for her teaching over the summer. After camp, Zoe continued to work with kids outside. She disclosed that,

I just started babysitting for a few different families on my street...I've been teaching them camp songs and we've been going out in their backyard and playing, and with one of them we even started to garden, which was pretty cool. At camp and during their interviews, Hazel (experimental group) and Josh (control group) talked about how excited they were to work as Outdoor School student leaders again in the fall (they had both volunteered during the previous school year). Celia (experimental group), who heard about Outdoor School from classmates and other assistant counselors, expressed interest during her interview in being an Outdoor School student leader. Similarly, Liza (control group) discussed how she hopes to be a camp counselor at the overnight camp she has attended for several summers. Adam (control 
group) mentioned that recently he had stepped into a leadership role with his Boy Scout group, leading activities with younger scouts during their camp-outs. Lastly, Kate (control group) concluded her interview by disclosing that her assistant counseling experience had helped her become more comfortable talking to people and be more outgoing in group settings and with her campers. 


\section{Discussion}

Participants of this study learned about the flora and fauna of Tryon Creek State Natural Area, developed a connection to place in the park, and gained skills and confidence in their youth leadership. The training program was successful in introducing participants to the concepts of interdependence and sustainability and facilitating their connection to place and sense of stewardship. However, more research is needed in order to determine the effectiveness of using sustainability education to design outdoor education programs aiming to build ecological literacy and environmental stewardship in students.

The training program in this study can be improved upon and utilized in other settings for both instructional and research purposes. Additionally, the Burns model of sustainability pedagogy (Burns, 2011) can be a useful tool for educators and researchers aiming to design programs using a sustainability education framework. The place-based context and experiential and participatory learning process emphasized in the Burns model were particularly instrumental in the success of the training program in this study. Finally, with some improvements and site specific modifications, the Ecology and Interdependence Questionnaire can be a useful survey instrument for researchers needing to measure participants' ecology knowledge.

Foremost, it will be important for educators and researchers to find a way to attract participants to training programs such as the one in this study. Without a sufficiently large group, it is difficult to assess the effectiveness of training programs. Despite advance planning, advertising, personal invitations including detailed schedules, 
and incentives at the training such as free meals, fun activities, and the unique opportunity to camp at a state natural area, it was challenging to get assistant counselors to commit to the training program. The main reasons why attendance was low were that many assistant counselors were on vacation, had other commitments, or were reluctant to come to an overnight where they would not know anyone. Educators will need to be diligent in advertising their program and should run it for several years in a row so that the program becomes established and anticipated by possible attendees. The best solution would be to incorporate sustainability pedagogy into existing, mandatory training programs, rather than as an add-on. This would ensure attendance, and likely improve the quality of the training already being offered.

Improvements can be made to the content and design of the training program and the Tryon Creek summer camp program. Based on low EIQ scores on the stream ecology question, and participants' lingering questions about the creek after training, it was apparent that more focus should be placed upon riparian and fish ecology during training. Additionally, the camp program has a "creek day" each week during which campers do water quality testing. More emphasis should be placed on big ideas about stream ecology and how the stream is part of the entire watershed. If water quality tests are performed, it will be essential to provide the context for why they are important, especially for young campers who have not yet learned about water chemistry in school.

The training program focused more on plants than animals, and two of the participants were left feeling curious about the fauna of Tryon Creek. Future trainings should add more focus to animal behavior and ecology, perhaps including tracking skills 
and other ways to study animal behavior. Participants' responses on the final EIQ question about the desert southwest ecosystem were generally good, although most participants failed to mention that wolves were a keystone species in the desert ecosystem. Animal ecology could be explored in future trainings by assessing what keystone species may be present in the park.

In their interviews, participants were reluctant to label themselves as environmentalists, even if their attitudes and behaviors were environmentally friendly and they were interested in sustainability issues like climate change and invasive species management. Participants also reported that they would talk about the environment if it was brought up at school or by someone else, but that they were unlikely to start a discussion. In future trainings, and even at community meetings at places like Tryon Creek State Natural Area, it may be helpful to hold discussions about local environmental issues in order to help counselors, volunteers, and staff self-indentify as people who are concerned with sustainability and make plans for positive change. If communities create a culture of open dialog around environment concerns, counselors and volunteers may be more comfortable identifying themselves as an environmentalist. If the term "environmentalist" has a negative connotation to it, community leaders and educators might encourage volunteers to use terms like "environmental steward" or "sustainabilityconscious" instead. In sustainability education, it is crucial that non-dominant perspectives (i.e. the "environmentalist") are voiced (Burns, 2011; Orr, 2004), as this voice is often stifled by societal norms. Young leaders can take more ownership of their 
role as environmental stewards if they are given ample opportunity to connect to outdoor places and discuss environmental issues.

In order to make time for stream and animal ecology as well as discussions about local environmental issues, some components of the training program in this study can be omitted in the future. Participants did an ethnobotany activity (see Appendix A for a detailed description) where they designed and constructed a useful item out of plant materials. Participants did not seem to learn very much from the activity, and Hazel mentioned in her interview that it was the least helpful part of training. Additionally, many ecology concepts can be covered in one hike (i.e. food webs, nutrient cycles, biodiversity, etc.) and some flexibility is needed in choosing which topics to address. Educators should assess what students already know and present topics that are most needed depending on the group present.

\section{Using the Burns Model to (Re)Design Sustainability Programs}

Part of the ecological design process of the Burns model of sustainability pedagogy includes feedback loops - evaluation and redesign. The training program in this study is evaluated in terms of how effectively it incorporated the components of Burns model (content, perspectives, process, and context). This evaluation can serve as an example for educators aiming to (re)design their own courses or programs in order to meet the goals of sustainability education.

Content. According to the Burns model, educators should focus their course on a central sustainability theme. The training program in this study was focused on the 
concept of interdependence in forest ecosystems and sustainability in general.

Participants reported learning about how important each organism is in an ecosystem and how all organisms are connected. In the future, the training program may be more successful with a narrower focus. Choosing one sustainability issue related to interdependence could be more memorable and accessible for students. Two possible themes could be: protecting keystone species, or maintaining biodiversity and ecological resilience in forests.

Perspectives. Participants of the training completed a role-play activity in which they played the part of a key stakeholder in the issue of how to deal with reemerging wolf populations in Idaho. They struggled to empathize with groups who they did not necessarily agree with, but in the end they reached a consensus. During history and ethnobotany hikes, participants heard stories of how past residents (Native Americans, pioneers, and loggers) used the land. Societal norms relating to eating and cooking practices were questioned as participants gathered their own food, shared a waste-free meal, and discussed the current American food system over dinner. All of the diverse perspectives were a vital part of the training program. One improvement that could be made to future programs would be to choose a locally relevant environmental issue to explore (i.e. something related to Tryon Creek State Natural Area instead of a situation in Idaho). Participants may have been more open to other perspectives if they had been able to personally connect to the issue.

Process. Participants enjoyed the experiential and participatory style of the training program. Hazel mentioned in her interview that she found it helpful to discuss 
how to manage camper behavior as we did activities that assistant counselors would eventually lead with their campers, rather than reading a "handout" about behavior management. It also worked well to be flexible with the schedule in order to allow the participants to reflect, rest, or spend more time in an interesting discussion or activity. Formative assessment and metacognitive activities completed throughout the training program were crucial for evaluating how well learning goals were being met, and adapting teaching and learning methods accordingly.

Context. Perhaps the most successful aspect of the training program, and even the entire camp counseling experience, was participants' sense of place in nature that they heightened throughout the summer. At the end of the training program, participants expressed that they really enjoyed the two sense of place explorations and the nature yoga class. Their journal entries from these experiences were filled with artwork and thoughtful poems and reflections. Learning about ecology in an authentic setting was also instrumental in allowing participants to explore with their senses and visualize how they would relay what they learned to their campers. Several interviewees mentioned how important they thought it was for children to experience nature first hand and develop a connection to it in order to learn to respect and care for the natural world.

\section{Ecology and Interdependence Questionnaire Improvements}

Participants showed improvement in their Ecology and Interdependence Questionnaire (EIQ) scores over the summer, particularly on the question about invasive species. With some improvements to the survey instructions and scoring method, the EIQ 
could be even more useful for measuring ecology content knowledge gains. The questionnaire gave instructions to answer each question as thoroughly as possible at the top of the first page, yet many participants seemed to rush through the survey, only jotting down one or two ideas for some questions. Perhaps more explicitly asking participants to list every idea they can think of in each essay question would help draw out more useful responses in terms of measuring knowledge.

EIQ scoring methods could be improved by determining a baseline in quality of responses that are deemed acceptable. For example, some participants provided rich descriptions of native plants in question number one, whereas others gave a vague, yet technically true description. One participant listed "vine maple" which she described as, "shade tolerant tree, small palmate leaves." Another participant listed the more general name, "maple tree," which he described as "tree with leaves." While both answers are technically true, the first response reflects a much greater knowledge of maples. If future researchers were to use the Ecology and Interdependence Questionnaire (or a similar survey) it will be crucial to establish a baseline for acceptable answers. In the aforementioned example, perhaps the baseline would be that the plant be named to the species level and that the description be specific enough to distinguish the plant from others in the park or area.

The quality of responses on the EIQ may also have been diminished due to a less than ideal testing environment. Sixteen of the twenty-two participants took their pretest on June 24, 2011 after an assistant counselor meeting. These participants sat outside in a covered shelter area. Clipboards and pens were available and it was quiet. The other six 
participants had to take their pretest on the Monday morning of their first week at camp because they did not attend the June meeting. It was unclear whether these participants' EIQ scores could have been better under a less stressful testing environment. (See Appendix G to compare EIQ scores between participants that took the questionnaire after the meeting on June 24th, 2011 and those that took the questionnaire on the morning of their first week at camp). All participants had to take their posttests on Friday afternoon of their last week of camp, except for a few individuals who requested that they be able to fill it out at home and send it via email or snail mail. Taking the EIQ before or after a day at camp was not ideal. The classroom where everyone was getting ready or cleaning up was crowded and noisy and often the participants were under pressure to finish quickly because they were being asked to help with one task or another as they were taking the survey. In a busy camp setting it is challenging to provide sufficient time or a quiet space to take a survey. Perhaps a few meetings outside of camp time could be organized when several participants could come take the posttest (such as the meeting on June 24th when most participants took the pretest). It is also important to simply remind participants to take their time, to provide them a quiet space to sit, and to thank them for their time and thoughtfulness.

This study could also be expanded upon by doing follow-up EIQ and NEP Scale posttests several months after camp in order to see if participants retained their ecology knowledge and sense of environmental stewardship. In the study conducted by Stern et al. (2008), participants did a three month post survey after an environmental education program and it was discovered that students retained their sense of stewardship and 
knowledge of biodiversity, but that after the elapsed time their connection with nature and interest in discovery began to diminish. It would be interesting to see which elements of the ecology of Tryon Creek State Natural Area were retained by assistant counselors several months after their camp experience, and which concepts were forgotten.

\section{Conclusion}

This study illuminated what young leaders learn and experience during their work at a nature themed camp, as well as what can be learned from an intensive sustainable ecology training program. More research is needed to determine a causal link between participation in such trainings and increased ecology knowledge and improved environmental attitudes and teaching skills. However, it was clear after interviewing participants that they learned about the flora and fauna and ecology of Tryon Creek State Natural Area both through the training program as well as through their experience assistant counseling. Additionally, participants entered the summer with fairly positive environmental attitudes, but during interviews they reported various ways that camp influenced their thoughts and behavior regarding sustainability issues like protecting riparian areas, composting and recycling, and getting children interested in the natural world.

Sustainability education (Burns, 2011) should be used as a framework for designing training programs for young leaders. Additionally, more teens should be encouraged to work for outdoor leadership programs, especially teens from underserved communities who may not have grown up spending time in nature (Roberts \& Suren, 
2010). Building connections with and learning about the natural world are the first steps toward developing a strong sense of environmental stewardship, which is needed to ensure a livable future for the coming generations. 


\section{References}

Bruntland, G. (ed.) (1987). Our Common Future: The World Commission for Environment and Development. Oxford: Oxford University Press.

Burns, H. (2011). Teaching for transformation: (Re)Designing sustainability courses based on ecological principles. Journal of Sustainability Education, 2.

Capra, F. (2005). Speaking nature's language: Principles for sustainability. In M. K. Stone \& Z. Barlow (Eds.), Ecological literacy: Educating our children for a sustainable world (pp. 18-29). San Francisco: Sierra Club Books.

Carrier, S. (2009). The effects of outdoor science education lessons with elementary school students on preservice teachers' self-efficacy. Journal of Elementary Science Education, 21(2), 35-48.

Colucci-Gray, L., Camino, E., Barbiero, G., \& Gray, D. (2006). From scientific literacy to sustainability literacy: An ecological framework for education. Science Education, 90, 227-252.

Dunlap, R.E. \& Van Liere, K.D. (1978). The "new environmental paradigm": A proposed measuring instrument and preliminary results. Journal of Environmental Education, 9, 10-19.

Dunlap, R.E., Van Liere, K.D., Mertig, A., \& Jones, R. (2000). Measuring endorsement of the New Ecological Paradigm: A revised NEP Scale. Journal of Social Issues, $56(3), 425-442$. 
Eng, M. J. (2006). Student Preparation Workbook for the Multnomah Outdoor Education Program. Retrieved from http://www.mesd.k12.or.us/os/Outdoor School/Classroom_Resources_files/Complete\%20Textbook.pdf

Glaser, B.G., \& Strauss, A. (1967) Discovery of Grounded Theory. Strategies for Qualitative Research. Mill Valley, CA.: Sociology Press.

Gilbert, R. (2003). Ecotourism and education for sustainability: A critical approach. International Review for Environmental Strategies, 4(1), 75-83.

Higgins, P. (1996). Outdoor education for sustainability: Making connections. Journal of Outdoor Adventure and Experiential Learning, 1(4), 4-11.

Higgins, P. \& Kirk, G. (2006). Sustainability education in Scotland: The impact of national and international initiatives on teacher education and outdoor education. Journal of Geography in Higher Education, 30(2), 313-326.

Lugg, A. (2007). Developing sustainability-literate citizens through outdoor learning: possibilities for outdoor education in Higher Education. Journal of Adventure Education and Outdoor Learning, 7(2), 97-112.

Moseley, C., Reinke, K., \& Bookout, V. (2002). The effect of teaching outdoor environmental education on preservice teachers' attitudes toward self-efficacy and outcome expectancy. The Journal of Environmental Education, 34(1), 9-15.

Oregon Department of Education (ODE). (2009) Oregon Science K-HS Content Standards. Retrieved from http://www.ode.state.or.us/search/page/?=2560

Orr, D. (1992). Ecological literacy: Education and the transition to a postmodern world. Albany, NY: State University of New York. 
Orr, D. (2005). Place and pedagogy. In M. K. Stone \& Z. Barlow (Eds.), Ecological literacy: Educating our children for a sustainable world (pp. 85-95). San Francisco: Sierra Club Books.

Preston, L. \& Griffiths, A. (2004). Pedagogy of connections: Findings of a collaborative action research project in outdoor and environmental education. Australian Journal of Outdoor Education, 8(2), 36-45.

Roberts, N.S. \& Suren, A.T. (2010). Through the eyes of youth: A qualitative evaluation of outdoor leadership programs. Journal of Park and Recreation Administration, 28(4), 59-80.

Sterling, S. (2002). Sustainable education: Re-visioning learning and change. Devon, UK: Green Books

Stern, M.J., Powell, R.B., \& Ardoin, N.M. (2008). What difference does it make? Assessing outcomes from participation in a residential environmental education program. The Journal of Environmental Education, 39(4), 31-43.

Thapa, B. (2010). The mediation effect of outdoor recreation participation on environmental attitude-behavior correspondence. The Journal of Environmental Education, 41(3), 133-150.

Trochim, W. M. (2006, Oct 20). The research methods knowledge base, 2nd Edition. Retrieved from http://www.socialresearchmethods.net/kb/ 


\title{
Interdependence and Sustainability
}

\author{
A leadership and ecology training for Assistant Counselors at \\ Tryon Creek Nature Day Camp \\ Friday June 24th - Sunday June 26th, 2011
}

"Sustainable development meets the needs of the present without compromising the ability of future generations to meet their own needs."

-Brundtland Commission of the United Nations

"A sustainable society... does not undermine the resource base and biotic stocks on which its future prosperity depends."

- David Orr 


\title{
Assistant Counselor Training Schedule: June 24th - 26th
}

\author{
All training sessions will include a hike, interactive activities and guided journaling.
}

\section{Friday}

We will begin when the general AC orientation with Casey and the rest of the Tryon staff concludes.

3:00 - Take two written surveys (if you are participating in Annie's study)

3:30 - Icebreakers and games

4:30 - Hike

5:00 - Break

5:30 - Dinner

6:30 - Training goals and expectations, concept map activity, journaling

7:00 - Ethnobotany design project

9:30 - Social hour and games

10:30 - Campout in the covered shelter*

\section{Saturday}

8:00 - Breakfast

9:00 - Training session 1: Biodiversity and interdependence of life

12:00 - "Waste-free lunch"

1:00 - Break

1:30 - Training session 2: Forest carbon and nitrogen cycles, life cycles

4:30 - Break

5:30 - Dinner

6:30 - Environmental issue role-play

8:00 - Play and learn camp games

9:00 - Candlelight campfire and wish-boat ceremony

10:00 - Social time

10:30 - Campout on the covered shelter*

\section{Sunday}

$7: 30$ - Nature yoga

8:30 - Breakfast

9:00 - Training session 3: Interdependence and sustainability

10:30 - Break

10:45 - Training session 4: Environmental conservation at Tryon Creek State Park

12:15 - Lunch

1:00 - Concept map revisited, final reflection and self evaluation

2:00 - Departure

* If the weather is wet or cold, we will sleep in the Kraft Room inside the nature center. 


\section{Training Objectives and Goals}

Objective \#1: I can explain in depth how to be an environmental steward and I have developed a sense of place in the natural world.

Objective \#2: I can describe living and non-living components of an ecosystem and explain how those components are interconnected.

What do you already know about the history and ecology of Tryon Creek Natural Area?

What are your expectations for the training?

What are your learning goals for this weekend? 


\section{Ethnobotany Engineering Design Assignment Guide}

\section{Background}

Ethnobotany is the study of how and why people use plants in their local environment. Often ethnobotany is studied in a historical or cultural context. For this project we are going to examine the ways that Native Americans of the Pacific Northwest used plants in their everyday lives. You will then use local plant materials to create a tool or other object that would be useful to someone living in Oregon prior to the arrival of Lewis and Clark.

\section{Identifying and Defining a Need to be Met}

Imagine that you are a Native American living in Oregon. Think of something that you might need to make everyday life easier (i.e. baskets, cookware, food, medicine, tools, boats, fishing and hunting supplies, clothing, jewelry, or shelter).

\section{Generating Possible Solutions and Designing a Product}

Once you have decided what you need, design that item using only local plant materials. Draw your design(s) and list all of the necessary materials in your journal. Then we will decide if those materials can be sustainably gathered from the forest. If so, you may gather just what you need. If not, you will need to slightly modify your design. You will be provided with some simple plant materials and craft supplies.

\section{Constructing the Products and Testing Solution(s)}

Make your product or tool, a part of it, or a model of it and test to see if it works. Write down observations and ideas for improvements in your journal. Make any fixes or refinements to your product or tool and test it again, continuing to note observations in your journal.

\section{Evaluating and Presenting the Results}

At the end of this evening you will present your object to the group. Explain what it is for, what materials you used, how you made it, and then demonstrate how it works. Discuss the strengths and weaknesses of your design, make suggestions for improvements, and discuss if it can be constructed in a sustainable manner. See the self assessment on the back of this page to help you plan your presentation.

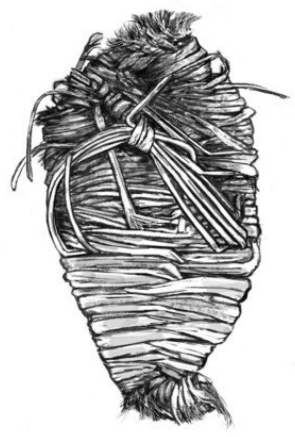




\section{Self-assessment for Ethnobotany Design Project Presentations}

\begin{tabular}{|c|c|c|c|}
\hline Circle one & $\begin{array}{c}\text { Identifying and Defining a } \\
\text { Need to be Met }\end{array}$ & $\begin{array}{l}\text { Generating Possible Solutions } \\
\text { and Designing a Product }\end{array}$ & Circle one \\
\hline $\begin{array}{l}\text { Your tribe } \\
\text { names you } \\
\text { master } \\
\text { sustainable } \\
\text { ethno- } \\
\text { botanist! }\end{array}$ & $\begin{array}{l}\text { Identifies and defines a need that } \\
\text { can be met through the process } \\
\text { of designing a tool or product } \\
\text { out of simple and readily } \\
\text { available plant materials. }\end{array}$ & $\begin{array}{l}\text { Uses knowledge of ethnobotany } \\
\text { and Native American history to } \\
\text { design multiple products/tools } \\
\text { that would serve the defined } \\
\text { need. }\end{array}$ & $\begin{array}{c}\text { Your tribe } \\
\text { names you } \\
\text { master } \\
\text { sustainable } \\
\text { ethno- } \\
\text { botanist! }\end{array}$ \\
\hline $\begin{array}{c}\text { You could } \\
\text { trade it for a } \\
\text { cool } \\
\text { arrowhead }\end{array}$ & $\begin{array}{l}\text { Identifies a useful product or } \\
\text { tool that can be made from plant } \\
\text { materials. }\end{array}$ & $\begin{array}{l}\text { Designs a product/tool using } \\
\text { readily available plant } \\
\text { materials. }\end{array}$ & $\begin{array}{l}\text { You could } \\
\text { trade it for a } \\
\text { cool } \\
\text { arrowhead }\end{array}$ \\
\hline $\begin{array}{l}\text { Won't last a } \\
\text { day in the } \\
\text { forest }\end{array}$ & $\begin{array}{l}\text { Identifies a product that cannot } \\
\text { be adequately fabricated with } \\
\text { plant materials. }\end{array}$ & $\begin{array}{l}\text { Haphazardly chooses materials } \\
\text { for product and/or does not } \\
\text { draw a design. }\end{array}$ & $\begin{array}{l}\text { Won't last a } \\
\text { day in the } \\
\text { forest }\end{array}$ \\
\hline
\end{tabular}

\begin{tabular}{|c|c|c|c|}
\hline Circle one & $\begin{array}{l}\text { Constructing the Products } \\
\text { and Testing Solution(s) }\end{array}$ & $\begin{array}{l}\text { Evaluating and Presenting the } \\
\text { Results }\end{array}$ & Circle one \\
\hline $\begin{array}{c}\text { Your tribe } \\
\text { names you } \\
\text { master } \\
\text { sustainable } \\
\text { ethno- } \\
\text { botanist! }\end{array}$ & $\begin{array}{l}\text { Constructs a product or tool } \\
\text { from simple plant materials } \\
\text { that meets the predetermined } \\
\text { need, tests the effectiveness } \\
\text { and utility of the product, and } \\
\text { modifies the design as needed. }\end{array}$ & $\begin{array}{l}\text { Evaluates how well the product } \\
\text { meets the predetermined need and } \\
\text { whether it could be produced } \\
\text { sustainably for an entire } \\
\text { community. Makes } \\
\text { recommendations for } \\
\text { modifications and improvements to } \\
\text { a future design. }\end{array}$ & $\begin{array}{c}\text { Your tribe } \\
\text { names you } \\
\text { master } \\
\text { sustainable } \\
\text { ethno- } \\
\text { botanist! }\end{array}$ \\
\hline $\begin{array}{l}\text { You could } \\
\text { trade it for a } \\
\quad \text { cool } \\
\text { arrowhead }\end{array}$ & $\begin{array}{l}\text { Constructs a product or tool } \\
\text { using plant materials and tests } \\
\text { to see if it works. }\end{array}$ & $\begin{array}{l}\text { Evaluates how well the product } \\
\text { works and how useful it is. Makes } \\
\text { recommendations for changes to a } \\
\text { future design. }\end{array}$ & $\begin{array}{l}\text { You could } \\
\text { trade it for a } \\
\text { cool } \\
\text { arrowhead }\end{array}$ \\
\hline $\begin{array}{l}\text { Won't last a } \\
\text { day in the } \\
\text { forest }\end{array}$ & $\begin{array}{c}\text { Constructs a product that is } \\
\text { unfinished or does not serve } \\
\text { any purpose. }\end{array}$ & $\begin{array}{l}\text { Incompletely evaluates how well } \\
\text { the product works and whether it } \\
\text { serves any purpose. Does not make } \\
\text { recommendations for } \\
\text { modifications. }\end{array}$ & $\begin{array}{l}\text { Won't last a } \\
\text { day in the } \\
\text { forest }\end{array}$ \\
\hline
\end{tabular}




\section{Ethnobotany Design Project}

- Brainstorm ideas for your product or tool.

- Draw a design of your product or tool.

- Record your observations as you build, test, and refine your item.

$\circ$ List the strengths and weaknesses of your design and how you could improve it in the future.

- How might culture and societal norms influence how you choose your item, what materials you use, how you make it, and how you will use your item? 


\section{Biodiversity and Interdependence Hike}

Listen to "Interdependence" in Ecological Literacy. How does interdependence relate to the sustainability of a forest ecosystem?

Listen to "Thinking Like a Mountain" in A Sand County Almanac by Aldo Leopold.

Draw a food web for the ecosystem in the story (the desert southwest). Then draw a food web for the Tryon Creek ecosystem. 


\section{Developing a Sense of Place (part 1)}

Spend about 30 minutes by yourself in the forest. Explore your surroundings using one of the following "lenses": experiential, scientific, artistic, historical, literary, transcendental, or your own idea.

Reflect on your observations, thoughts, feelings, ideas, or insights that arise from the experience. 


\section{Forest Nutrient Cycles and Life Cycles}

Draw a diagram of the forest carbon cycle. 


\section{$\underline{\text { Transforming an Environmental Problem }}$}

What role did you play in the discussion?

How did you relate to your character?

How was the problem transformed? Was a consensus reached?

What was frustrating about the discussion?

What did you learn from this activity? 


\section{Developing a Sense of Place (part 2)}

Reflect on your experience in the nature yoga class. What was it like to practice yoga in the forest?

Spend about 20 minutes by yourself in the forest and explore your surroundings using a different lens than yesterday. Reflect on your observations, thoughts, feelings, ideas, or insights that arise from the experience. 


\section{$\underline{\text { Sustainability }}$}

What are some threats to living sustainably with the land?

What might this mean for future generations?

How can we care for the earth and our children and grandchildren? 


\section{Environmental Quality Evaluation}

What environmental disturbances did you observe on the hike?

What do you think the five biggest environmental problems are at Tryon Creek Natural Area?

What are some possible solutions to these problems? 


\section{$\underline{\text { Assistant Counselor Self-Assessment }}$}

For both training objectives, please rate yourself on a scale of 1 to 6 for each component and answer the follow-up questions.

Objective \#1: I can explain in depth how to be an environmental steward and I have developed a sense of place in the natural world.

\begin{tabular}{|l|l|l|}
\hline $\begin{array}{l}\text { no knowledge of how humans impact the } \\
\text { environment }\end{array}$ & to & $\begin{array}{l}\text { able to explain how humans' choices can } \\
\text { positively or negatively affect the } \\
\text { environment }\end{array}$ \\
\hline
\end{tabular}

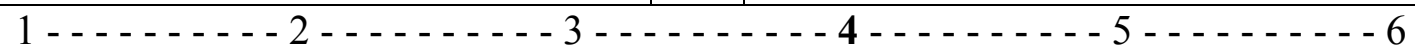

Novice Proficient Expert

\begin{tabular}{|l|l|l|}
\hline $\begin{array}{l}\text { unable to express ideas about science and } \\
\text { the environment }\end{array}$ & to & $\begin{array}{l}\text { can engage in scientific and political } \\
\text { discussions about environmental issues }\end{array}$ \\
\hline
\end{tabular}

$1-\ldots-\ldots 2-\ldots-\ldots$

Novice Proficient Expert

\begin{tabular}{|l|l|l|}
\hline $\begin{array}{l}\text { no knowledge of how to interact with and } \\
\text { understand the natural world }\end{array}$ & to & $\begin{array}{l}\text { engages with the natural world through a } \\
\text { variety of different methods and lenses }\end{array}$ \\
\hline
\end{tabular}

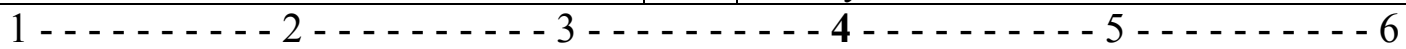

Novice Proficient Expert

\begin{tabular}{|l|l|l|}
\hline $\begin{array}{l}\text { no knowledge of how Native Americans } \\
\text { lived sustainably off the land }\end{array}$ & to & $\begin{array}{l}\text { can describe how Native Americans lived } \\
\text { and used natural resources in a sustainable, } \\
\text { low-impact manner }\end{array}$ \\
\hline
\end{tabular}

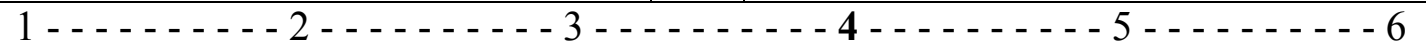

Novice Proficient Expert

\begin{tabular}{|l|l|l|}
\hline $\begin{array}{l}\text { not able to design and fabricate a tool or } \\
\text { useful item using simple plant materials }\end{array}$ & to & $\begin{array}{l}\text { able to design, fabricate, and make } \\
\text { refinements to a tool or other useful item } \\
\text { using renewable plant resources }\end{array}$ \\
\hline
\end{tabular}

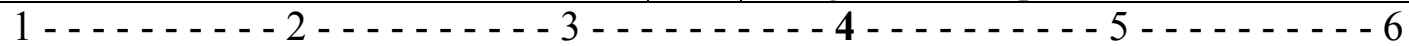

Novice Proficient Expert

Please explain how you can be a steward of the environment at Tryon Creek this summer.

Describe how you have developed a sense of place here at Tryon Creek. 
Objective \#2: I can describe living and non-living components of an ecosystem and explain how those components are interconnected.

\begin{tabular}{|c|l|l|}
\hline $\begin{array}{l}\text { can point out a living organism in an } \\
\text { ecosystem }\end{array}$ & to & $\begin{array}{l}\text { can describe and classify living } \\
\text { organisms in an ecosystem (plants, } \\
\text { animals, fungi, bacteria, etc.) }\end{array}$ \\
\hline $\begin{array}{l}\text { Novice } \\
\text { Proficient }\end{array}$ & Expert
\end{tabular}

\begin{tabular}{|c|l|l|}
\hline $\begin{array}{l}\text { no knowledge of how living and non- } \\
\text { living things interact in an ecosystem }\end{array}$ & to & $\begin{array}{l}\text { can explain how living organisms } \\
\text { interact with each other and the non- } \\
\text { living environment }\end{array}$ \\
\hline $\begin{array}{c}\text { Novice } \\
\text { Proficient }\end{array}$
\end{tabular}

\begin{tabular}{|c|c|c|}
\hline no knowledge of food webs & to & $\begin{array}{l}\text { can draw a diagram of a complex food } \\
\text { web in an ecosystem }\end{array}$ \\
\hline Novice & fici & $\begin{array}{c}\text { Expert } \\
t\end{array}$ \\
\hline
\end{tabular}

\begin{tabular}{|c|c|c|}
\hline no knowledge of nutrient cycles & to & $\begin{array}{l}\text { can draw a diagram of the nitrogen and } \\
\text { carbon cycles }\end{array}$ \\
\hline Novice & fici & $\begin{array}{c}--------6 \\
\text { Expert }\end{array}$ \\
\hline
\end{tabular}

What are some of the most interesting things that you have learned about the ecology of Tryon Creek forest this weekend?

What concepts do you think will be the most useful for teaching to your campers this summer?

What questions do you still have about the ecology of the forest? 


\section{Appendix B: Lesson Plans for the Training Program}

Friday Session 1 3:00 - 5:00, Dinner 5:30-6:00, Project 7:00 - 9:30, Social hour 9:30-10:30

\begin{tabular}{|c|c|c|}
\hline Friday afternoon & Friday evening & Friday night \\
\hline $\begin{array}{l}\text { Concept Strand: } \\
\text { Introduction and Icebreakers }\end{array}$ & $\begin{array}{l}\text { Concept Strand: Introduce } \\
\text { themes and set goals. }\end{array}$ & $\begin{array}{l}\text { Concept Strand: } \\
\text { Ethnobotany design project }\end{array}$ \\
\hline $\begin{array}{l}\text { Learning Goals: Students } \\
\text { will be more comfortable } \\
\text { with each other and Tryon } \\
\text { Creek State Park. }\end{array}$ & $\begin{array}{l}\text { Learning Goals: Students } \\
\text { will be able to explain in } \\
\text { depth how one can be a } \\
\text { steward of the environment }\end{array}$ & $\begin{array}{l}\text { Learning Goals: Students can describe } \\
\text { how Native Americans lived and used } \\
\text { natural resources in a sustainable, low- } \\
\text { impact manner and will be able to } \\
\text { design, fabricate, and make refinements } \\
\text { to a tool or other useful item using } \\
\text { renewable plant resources }\end{array}$ \\
\hline $\begin{array}{l}\text { Strategies: } \\
\text { O Administer NEP Scale } \\
\text { and Ecology and } \\
\text { Interdependence } \\
\text { Questionnaire } \\
\text { Icebreakers: Name game, } \\
\text { World Map Game, } \\
\text { Forced Choice, Pair and } \\
\text { Share Interviews } \\
\text { Initiatives: Monkey See } \\
\text { (partners try to get their } \\
\text { buddy to perform } \\
\text { "dance" without } \\
\text { speaking), Floating Stick, } \\
\text { Trust Sit } \\
\text { Hike: Intro to } \\
\text { Ethnobotany and plant } \\
\text { and animal ID. }\end{array}$ & $\begin{array}{l}\text { Strategies: } \\
\text { O Introduce big idea, } \\
\text { subtopics, framework, } \\
\text { and goals for the } \\
\text { training. } \\
\text { Concept mapping: } \\
\text { Students create group } \\
\text { concept map using } \\
\text { post-its. Theme: “What } \\
\text { is environmental } \\
\text { stewardship?" } \\
\text { Make training journals. } \\
\text { Journal: Expectations } \\
\text { and goals for the } \\
\text { training, prior } \\
\text { knowledge of Tryon, } \\
\text { ecology, natural } \\
\text { history, etc. }\end{array}$ & $\begin{array}{l}\text { Strategies: } \\
\text { Introduction to ethnobotany and } \\
\text { local Native American history: } \\
\text { look at artifacts and photos. } \\
\text { Read "Roundhouse" essay from } \\
\text { Ecological Literacy. } \\
\text { Pass out ethnobotany design } \\
\text { project description and introduce } \\
\text { assignment. } \\
\text { Students brainstorm, draw designs, } \\
\text { and share ideas and feedback with } \\
\text { peers. } \\
\text { Students collect materials and } \\
\text { construct their products. } \\
\text { Students pilot test products, record } \\
\text { observations, and modify their } \\
\text { designs. } \\
\text { Students do a final test of their } \\
\text { product and list strengths and } \\
\text { weaknesses of their design. } \\
\text { Students present projects and } \\
\text { demonstrate how they work. } \\
\text { (Rubrics for feedback) }\end{array}$ \\
\hline State Standards: & State Standards: & State Standards: H.4D.1, H.4D.2 \\
\hline Materials: rope, Nerf balls & $\begin{array}{l}\text { Materials: post-its, } \\
\text { journals, construction } \\
\text { paper, markers, yarn, hole } \\
\text { punch }\end{array}$ & $\begin{array}{l}\text { Materials: Ethnobotany design } \\
\text { assignment worksheet, Ecological } \\
\text { Literacy, plant materials (grasses, cedar } \\
\text { bark, wood, etc.), and simple hand } \\
\text { tools. }\end{array}$ \\
\hline
\end{tabular}

Note. Purple highlighted items are outdoor activities

Green highlighted items are journaling prompts

Blue highlighted items are assessments 


\begin{tabular}{|c|c|c|c|}
\hline \multicolumn{4}{|c|}{$\begin{array}{l}\text { Saturday Breakfast 8:00 - 8:30, Session 1 9:00 - 12:00, Waste free lunch 12:00 - 1:00, Session } 2 \\
\text { 1:30-4:30, Dinner 5:00 - 6:00, Role-play 6:30 - 8:00, Night Hike, Campfire, and Games 8:00 - 10:00 }\end{array}$} \\
\hline Saturday morning & Saturday afternoon & Saturday evening & Saturday night \\
\hline $\begin{array}{l}\text { Concept Strand: } \\
\text { Biodiversity and } \\
\text { Interdependence. }\end{array}$ & $\begin{array}{l}\text { Concept Strand: } \\
\text { Nutrient cycling, } \\
\text { interdependence } \\
\text { continued. }\end{array}$ & $\begin{array}{l}\text { Concept Strand: } \\
\text { Environmental issues } \\
\text { role play }\end{array}$ & $\begin{array}{l}\text { Concept Strand: } \\
\text { Night hike, games, } \\
\text { campfire, and } \\
\text { social hour. }\end{array}$ \\
\hline $\begin{array}{l}\text { Learning Goals: Students } \\
\text { can describe and classify } \\
\text { living organisms in an } \\
\text { ecosystem, can draw a } \\
\text { diagram of a complex food } \\
\text { web in an ecosystem, and can } \\
\text { engage with the natural world } \\
\text { through a variety of lenses. }\end{array}$ & $\begin{array}{l}\text { Learning Goals: } \\
\text { Students can explain } \\
\text { how living organisms } \\
\text { interact with each other } \\
\text { and the non-living } \\
\text { environment, can draw a } \\
\text { diagram of the carbon } \\
\text { cycle. }\end{array}$ & $\begin{array}{l}\text { Learning Goals: } \\
\text { Students can engage in } \\
\text { scientific and political } \\
\text { discourse about } \\
\text { environmental issues. }\end{array}$ & $\begin{array}{l}\text { Learning Goals: } \\
\text { Students will learn } \\
\text { games, songs, and } \\
\text { skits to use with } \\
\text { their campers. }\end{array}$ \\
\hline $\begin{array}{l}\text { Strategies: } \\
\text { Hike: Biodiversity of } \\
\text { plants, animals, and } \\
\text { fungi at Tryon. ID } \\
\text { species \& discuss life } \\
\text { cycles and food webs. } \\
\text { Read "Interdependence" } \\
\text { from Ecological } \\
\text { Literacy. } \\
\text { Sense of place: ACs } \\
\text { spend } 30 \text { minutes alone } \\
\text { using a chosen lens for } \\
\text { connecting to Tryon } \\
\text { (literary, artistic, } \\
\text { experiential, or } \\
\text { scientific). Journal about } \\
\text { the experience. } \\
\text { Waste-free lunch: } \\
\text { produce zero waste from } \\
\text { lunch, show worm } \\
\text { compost bin, eat apple } \\
\text { cores, etc. }\end{array}$ & $\begin{array}{l}\text { Strategies: } \\
\text { Nurse log concept } \\
\text { cartoon } \\
\text { Discuss soil } \\
\text { composition, plant } \\
\text { macronutrients } \\
\text { (NPK), and } \\
\text { decomposers. } \\
\text { Kinesthetic activity: } \\
\text { students enact the } \\
\text { carbon cycle. } \\
\text { Hike: Hunt for } \\
\text { evidence of } \\
\text { nutrients moving } \\
\text { through forest } \\
\text { ecosystem. Read } \\
\text { "Thinking Like a } \\
\text { Mountain" by Aldo } \\
\text { Leopold. Collect } \\
\text { nettles for dinner. } \\
\text { Journal: Guided } \\
\text { reflection from } \\
\text { readings \& draw } \\
\text { food webs \& } \\
\text { diagram of the flow } \\
\text { of nutrients through } \\
\text { an ecosystem. }\end{array}$ & $\begin{array}{l}\text { Strategies: } \\
\text { Sustainable harvest } \\
\text { dinner: nettle pasta, } \\
\text { discuss eating local } \\
\text { and organic, slow } \\
\text { food values } \\
\text { Present news story } \\
\text { about wolves re- } \\
\text { entering former } \\
\text { territory in Idaho } \\
\text { and impact on local } \\
\text { communities and } \\
\text { surrounding biotic } \\
\text { community. } \\
\text { Assign students a } \\
\text { role (stakeholder in } \\
\text { the issue) and give } \\
\text { time to journal their } \\
\text { viewpoint in the } \\
\text { scenario. } \\
\text { Facilitate student } \\
\text { role-play with the } \\
\text { goal of transforming } \\
\text { problem into win- } \\
\text { win situation. }\end{array}$ & $\begin{array}{l}\text { Strategies: } \\
\text { Night Hike: } \\
\text { New moon, } \\
\text { discuss night } \\
\text { vision and rod } \\
\text { and cone cells } \\
\text { in owl eyes. } \\
\text { Tealight } \\
\text { campfire with } \\
\text { songs and } \\
\text { stories. } \\
\text { Game: } \\
\text { Psychologist, } \\
\text { cup passing } \\
\text { games. } \\
\text { Popcorn and } \\
\text { social time. }\end{array}$ \\
\hline $\begin{array}{l}\text { State Standards: K.1L.1, } \\
\text { 1.2L.1, 2.1L.1, 3.2L.1, } \\
\text { 4.2L.1, 5.2L.1 }\end{array}$ & $\begin{array}{l}\text { State Standards: } \\
\text { H.1E.2, H.2L.1, H.2E.1 }\end{array}$ & $\begin{array}{l}\text { State Standards: } \\
\text { H.2E.4, H.4D.1 }\end{array}$ & State Standards: \\
\hline $\begin{array}{l}\text { Materials: Hike props, field } \\
\text { guides, Ecological Literacy, } \\
\text { art supplies, and journals. }\end{array}$ & $\begin{array}{l}\text { Materials: White board, } \\
\text { nutrient cycle cards, } A \\
\text { Sand County Almanac, } \\
\text { and journals }\end{array}$ & $\begin{array}{l}\text { Materials: News story, } \\
\text { journals. }\end{array}$ & $\begin{array}{l}\text { Materials: } \\
\text { Songbooks, } \\
\text { journals. }\end{array}$ \\
\hline
\end{tabular}


Sunday Yoga 7:30 - 8:30, Breakfast 8:30 - 9:00, AM Session 19:00 - 10:30, AM Session 2 10:30 - 12:15, Lunch 12:15 - 1:00, Final reflection and concept mapping 1:00 - 2:00, Depart 2:00

\begin{tabular}{|c|c|c|}
\hline Sunday morning & Sunday morning & Sunday afternoon \\
\hline $\begin{array}{l}\text { Concept Strand: } \\
\text { Interdependence and } \\
\text { sustainability. History of land } \\
\text { use at Tryon. }\end{array}$ & $\begin{array}{l}\text { Concept Strand: } \\
\text { Environmental issues at Tryon } \\
\text { Creek. }\end{array}$ & $\begin{array}{l}\text { Concept Strand: } \\
\text { Reflection and concept } \\
\text { mapping. }\end{array}$ \\
\hline $\begin{array}{l}\text { Learning Goals: Students } \\
\text { can describe how Native } \\
\text { Americans lived and used } \\
\text { natural resources in a } \\
\text { sustainable, low-impact } \\
\text { manner, able to explain how } \\
\text { one can be a steward of the } \\
\text { environment. }\end{array}$ & $\begin{array}{l}\text { Learning Goals: Students can } \\
\text { explain how humans' choices can } \\
\text { positively or negatively affect the } \\
\text { environment. }\end{array}$ & $\begin{array}{l}\text { Learning Goals: Students are } \\
\text { able to explain in depth how } \\
\text { one can be a steward of the } \\
\text { environment. }\end{array}$ \\
\hline $\begin{array}{l}\text { Strategies: } \\
\text { Y Yoga practice with } \\
\text { nature theme and second } \\
\text { sense of place experience } \\
\text { with a different "lens." } \\
\text { Journal about the } \\
\text { experience. } \\
\text { History Hike: Relate } \\
\text { indigenous and logging } \\
\text { history of Tryon. } \\
\text { Ethnobotany review. } \\
\text { Compare how Native } \\
\text { Americans lived with the } \\
\text { land to how we do now. } \\
\text { Journal: What are some } \\
\text { threats to living } \\
\text { sustainably with the } \\
\text { land? What might this } \\
\text { mean for future } \\
\text { generations? What can } \\
\text { we do about it? }\end{array}$ & $\begin{array}{l}\text { Strategies: } \\
\text { Hike (Guided by Education } \\
\text { Director of Friends of Tryon } \\
\text { Creek): Environmental quality } \\
\text { evaluation. Look for signs of } \\
\text { disturbances at Tryon: Invasive } \\
\text { species, erosion, pollution, } \\
\text { stream habitat loss, etc. } \\
\text { Discuss human impacts and } \\
\text { management options for Tryon. } \\
\text { Journal: What are the five } \\
\text { biggest environmental } \\
\text { problems at Tryon? What can } \\
\text { we do to solve them? } \\
\text { Wishboat ceremony: build } \\
\text { small boats out of forest floor } \\
\text { materials. Make a wish or goal } \\
\text { for the summer and sail boats } \\
\text { down the creek. }\end{array}$ & $\begin{array}{l}\text { Strategies: } \\
\text { O Concept mapping activity: } \\
\text { Repeat activity from } \\
\text { Friday. Students create } \\
\text { group concept map using } \\
\text { post-its. Theme: "What is } \\
\text { environmental } \\
\text { stewardship?" This time } \\
\text { students use a different } \\
\text { color of post-its and } \\
\text { modify and expand their } \\
\text { initial concept map. } \\
\text { Photograph concept map to } \\
\text { share with students. } \\
\text { Self assessment in journals. } \\
\text { Reflect upon learning } \\
\text { throughout the weekend } \\
\text { and changes in their } \\
\text { conceptions of } \\
\text { environmental stewardship. } \\
\text { Photocopy student journals } \\
\text { for assessment and } \\
\text { feedback. }\end{array}$ \\
\hline $\begin{array}{l}\text { State Standards: H.2L.2, } \\
\text { H.2E.4 }\end{array}$ & State Standards: H.2L.2, H.2E.4 & State Standards: \\
\hline $\begin{array}{l}\text { Materials: Yoga mats, hike } \\
\text { props, journals }\end{array}$ & $\begin{array}{l}\text { Materials: Photos of invasive, } \\
\text { journals }\end{array}$ & $\begin{array}{l}\text { Materials: different color post- } \\
\text { its, journals }\end{array}$ \\
\hline
\end{tabular}


Appendix C: Ecology and Interdependence Questionnaire (EIQ)

\section{Ecology and Interdependence Questionnaire}

Instructions: Answer the following questions as completely as possible. Use the back of the page if you need more space to write. If you do not know the exact name of a plant or animal, describe it as best you can.

1. Name and briefly describe five native plants and/or animals that are found at Tryon Creek State Natural Area.

\begin{tabular}{|l|l|l|}
\hline & Name of Plant or Animal & Description \\
\hline 1. & & \\
\hline 2. & & \\
\hline 3. & & \\
\hline 4. & & \\
\hline 5. & & \\
\hline
\end{tabular}

2. Describe the role that fallen trees and stumps have in a forest ecosystem over time.

3. What role do plants have in stream health and maintaining water quality? 
4. Name three invasive plant or animal species that are found in Tryon Creek State Natural Area. For one of these species, please describe its negative impacts on the ecosystem and how it can be managed.

\begin{tabular}{|l|l|l|}
\hline & Name of Invasive Species & Negative impacts and management options \\
\hline 1. & & \\
\hline 2. & & \\
\hline 3. & & \\
& & \\
& & \\
\end{tabular}

5. Early in the 20th century, wolves in the southwest United States began eating sheep and other livestock from farms and ranches. In response to complaints from ranchers who were losing their livestock, government land managers implemented a hunting program to control the wolf population. Study the following food web diagram for the desert ecosystem from the time before settlers moved in and established sheep and cattle ranches. How might the populations of the plants and animals shown in the food web have been impacted as a result of the wolf hunting program? Describe the shifts or changes in the food web that may have occurred on the back of this page.

Desert Southwest Food Web

Before the introduction of ranches

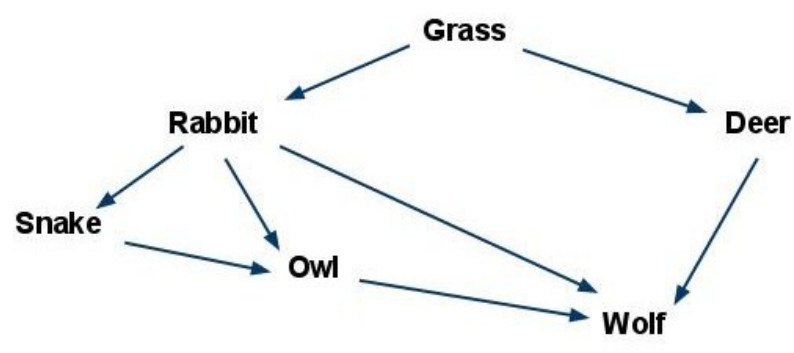




\section{Appendix D: Markscheme Scoring Guide for the EIQ}

\section{Ecology and Interdependence Questionnaire Markscheme}

Each question will be worth a total of five points. Bullet points list common possible correct answers. For essay questions (\#s 2, 3, and 5) 1 point will be awarded for each correct idea listed by the student, up to a maximum of 5 points. Incorrect responses will not receive point, nor will points be deducted.

1.

- Each native species or genus named and correctly described earns 1 point. Must be a native plant/animal commonly found in Tryon Creek State Park.

- Partial credit may be awarded for just naming a native species without providing a clear and correct description, or for naming non-specific plant or animal (i.e. owl vs. Great Horned owl, fern vs. sword fern).

2.

- Habitat for other plants, animals, fungi, etc.

- Food for decomposers and insectivores

- Turn into soil after decomposition

- Carbon/other nutrient deposition into soil

- "Standing dead" important for soil stabilization

- Part of tree life cycle, new trees grow out of old

- "Nurse" log/stump

- Provide riparian habitat

- Open tree canopy—-sunlight reaches forest floor

3.

- Cleaning/filtering water, removal of toxics from groundwater

- Erosion control and soil stabilization

- Temperature control: shade, erosion control, groundwater recharge cooler than runoff into streams 
- Canopy cover slows rainfall and infiltration rate and some water is evapotranspired from leaves rather than reaching the ground (prevents saturation and runoff)

- Roots create space for infiltration and take up water into plant (helps reduce saturation of soil)

- Course woody debris and riparian plants create ripples and rills which help increase DO in streams

- Plant detritus adds food and nutrients to stream for aquatic animals

- Habitat for fish: roots and logs provide pools, nursery areas, etc.

- Indicator/feedback: plant health reflects water quality

- Provide clean air around stream

4.

- One point earned for each non-native invasive species named (up to 3 points)

- One point earned for naming negative impacts of one invasive species

- One point earned for naming a management technique for an invasive species

5.

- Deer population boom

- Rabbit population increase

- Owl population increase

- Snake population impacts

- Overgrazing of grass, bare soil, erosion

- Deer and rabbit population would sharply drop once they overgrazed the land - food shortage

- Loss of homeostasis of ecosystem, difficult to recover from disturbance

- Management concerns: i.e. depletion of grass, bare soil, loss of grazing land

- Wolf population formerly was keeping deer/rabbit populations at level the land could sustain (keystone species) 


\title{
Appendix E: New Ecological Paradigm (NEP) Scale Form
}

\section{New Ecological Paradigm Scale}

\author{
Dunlap, Van Liere, Mertig and Jones (2000)*
}

Listed below are statements about the relationship between humans and the environment. For each one, please indicate whether you STRONGLY AGREE, MILDLY AGREE, are UNSURE, MILDLY DISAGREE or STRONGLY DISAGREE with it.

\begin{tabular}{|l|l|l|l|l|l|}
\hline Do you agree or disagree that: & $\begin{array}{l}\text { Strongly } \\
\text { Agree }\end{array}$ & $\begin{array}{l}\text { Mildly } \\
\text { Agree }\end{array}$ & Unsure & $\begin{array}{l}\text { Mildly } \\
\text { Disagree }\end{array}$ & $\begin{array}{l}\text { Strongly } \\
\text { Disagree }\end{array}$ \\
\hline $\begin{array}{l}\text { 1. We are approaching the limit of the number } \\
\text { of people the earth can support. }\end{array}$ & & & & & \\
\hline $\begin{array}{l}\text { 2. Humans have the right to modify the } \\
\text { natural environment to suit their needs. }\end{array}$ & & & & & \\
\hline $\begin{array}{l}\text { 3. When humans interfere with nature it often } \\
\text { produces disastrous consequences. }\end{array}$ & & & & & \\
\hline $\begin{array}{l}\text { 4. Human ingenuity will insure that we do } \\
\text { NOT make the earth unlivable. }\end{array}$ & & & & & \\
\hline $\begin{array}{l}\text { 5. Humans are severely abusing the } \\
\text { environment. }\end{array}$ & & & & & \\
\hline $\begin{array}{l}\text { 6. The earth has plenty of natural resources if } \\
\text { we just learn how to develop them. }\end{array}$ & & & & & \\
\hline $\begin{array}{l}\text { 7. Plants and animals have as much right as } \\
\text { humans to exist. }\end{array}$ & & & & & \\
\hline $\begin{array}{l}\text { 8. The balance of nature is strong enough to } \\
\text { cope with the impacts of modern industrial } \\
\text { nations. }\end{array}$ & & & & & \\
\hline $\begin{array}{l}\text { 9. Despite our special abilities humans are } \\
\text { still subject to the laws of nature. }\end{array}$ & & & & & \\
\hline $\begin{array}{l}\text { 10. The so-called "ecological crisis" facing } \\
\text { humankind has been greatly exaggerated. }\end{array}$ & & & & & \\
\hline $\begin{array}{l}\text { 11. The earth is like a spaceship with very } \\
\text { limited room and resources. }\end{array}$ & & & & & \\
\hline $\begin{array}{l}\text { 12. Humans were meant to rule over the rest } \\
\text { of nature. }\end{array}$ & & & & & \\
\hline $\begin{array}{l}\text { 13. The balance of nature is very delicate and } \\
\text { easily upset. }\end{array}$ & & & & & \\
\hline $\begin{array}{l}\text { 14. Humans will eventually learn enough } \\
\text { about how nature works to be able to control } \\
\text { it. }\end{array}$ & & & & & \\
\hline $\begin{array}{l}\text { 15. If things continue on their present course, } \\
\text { we will soon experience a major ecological } \\
\text { catastrophe. }\end{array}$ & & & & & \\
\hline
\end{tabular}

* Dunlap, R.E., Van Liere, K.D., Mertig, A., and Jones, R. (2000). Measuring endorsement of the New Ecological Paradigm: A revised NEP Scale. Journal of Social Issues. 56(3): 425-442. 


\title{
Appendix F: Interview Transcripts
}

\author{
Note: See Method section for interview questions 1 -11. Italicized text indicates \\ additional questions or comments from this researcher (AL).
}

\section{Interview with Josh, August 18, 2011}

1. I think one of my favorite memories this summer has been my second week with Maple [a staff member] for our ending presentation when we measured the elephant tree on Maple Ridge Trail, having all the kids get... we did it by measuring string lengths of their height and having all the kids measure them was really fun and memorable for me because the kids were six and seven years old, so you get some pretty funny numbers from counting. I had this one kid who was probably about four feet tall said it took 75 of him to make the whole tree, or to fill out the whole length of the tree. That was really funny... That kind of summarizes why I like working with kids, and younger kids especially. Because at this age they're still, they don't really have that great of a sense of reasonability for things like that, because they're still at the age where the number... they know their numbers but maybe they don't make complete sense. And also, I really like, this kind of ties in with it, at the end for our presentation how all the kids they had their own unique number that was personal to them that was the length of how many of them it took to measure the whole...tree. Which was really nice for each of them to have. Their own sense of uniqueness but still a group project because we're all working on the same tree but then each of them have their own different part. And I think it's important for kids to have that kind of sense of independency but also working with a bigger group, because obviously in this world you have to work with other people. You can't just be individual working by yourself. So it was just kind of fun to have it all get together.

2. There was by far, there was more challenging [moments]. Also my second week, I had two brothers named Ian and Sean [campers' names have been changed]. Ian was the older one, and he looked after Sean a lot, and usually what Ian did, Sean would follow and do the same. But we were walking back, I don't remember which trail it is...we came to a Y though, and then Maple asked the question, "Who wants to go back to the nature center a little longer out and get to hike more and explore more things, and then who wants to go the other route and be back at the nature center faster?" And then Sean and this other child named Carl said that they wanted to go the faster route and the rest of the kids all wanted to go the longer route and hike more. So... they started walking and Sean and Carl decided that they were just going to stay there and Carl, I don't really know how much he really didn't want to go, but he liked to stay back with me because I was always at the end. So he was there, I don't really know exactly how he felt, but Sean definitely was like, "Oh, I want to go the shorter way." So we sat there and for about...So first I was just like, "Oh come on, your brother," (cause I thought that might work) "your brother's going that way, we're going to go that way too." So maybe being together, that would work, but that didn't work. And then he decided to go up the trail and just sit down on this tree trunk. And he just sat there. And then I told him, "Oh okay, we can..." Oh and it was right after lunch too, and Maple had said we weren't going to run anymore. And then I was like, "okay we can run." He's like, "no, I don't want to run. I don't want to go the other way." And I was like, "Okay well we're going to have to compromise here about what we're going to do because we need to go with the rest of the group." And then finally after that I said, "So do you have any ideas for compromising?" And he's like, "Nope, the only thing I want to do is go the other way." And I was like, "Well that's not compromising because I'm not getting anything." And then he just kept on going on and on with that. And I tried every single thing I know how to get a child to do, and it didn't work. And by this time it was like ten or fifteen minutes, Maple and rest of the group were way long, and I already told him that we'd just spent all this time talking about while we could have already been back at the nature center. He still didn't take any... He still didn't care about that. He still wanted to just sit 
there. And then I tried grabbing him... that didn't help... not grabbing him, picking him up and physically moving him, because he was just so stubborn. He was sitting there. And then finally, I don't know what I did. I said I would carry their backpacks, so I carried both of their backpacks. I said we could run, so that was two things you're not really supposed to do. Cause Maple said we weren't going to run. And then I think that was it, but finally after like fifteen minutes Sean and Carl finally got up and started heading back with the rest of the group. But it was crazy. I didn't know what we were going to do. I think if it had been too much longer I would have just gone the other way and met up with Maple back here. It was very challenging.

3. I decided to work here because this summer...since I' $m$ in high school I've been kind of planning out my summers for the rest of high school and seeing what I need to do for the rest of my year. And I kind of decided that this year would be for volunteering and getting more experience on working with kids and children because that's something that I hope to do in the future. And next year, or next summer, I'm hoping to get more of a paid position somewhere at a different camp. So I decided that this would be a good summer to work with children, just gain more experience with a wider age range of kids. Because I've worked with sixth graders at Outdoor School and then I've also done some tutoring for foreign students that were around the sixth grade age, and then I've babysat before, but that's not really that much. So I haven't worked with like the K-5 age very much... And then the other camps, I've worked at Outdoor School for the past two sessions at Milk Creek, but unfortunately with the recent budget cuts, I'm not sure where that's going in the future with what's going on there, cause I'm going to have to switch camps and I don't know how many student leaders they're going to be taking next year. So I just thought that this would be a good learning experience for me, and gain more practice.

4. I think being out...like the invasive species...being out and like physically seeing what's going on in this State Park and all around Oregon, not just Oregon, everywhere, of other species that come here and that take over the native plants. It's interesting to see. Because I think a lot of people don't really understand what's going on. But I was driving on Barber the other day and just every single tree along there is just covered in ivy. And it's just really interesting to me because it doesn't seem like there will be a way to get rid of it anytime soon cause it just spreads so vastly. Just walking around here, I know they've done a really good job, around here, but just walking out today there's just so much of it and I don't know, it's just really interesting how it's taken over a lot of forests around here and everywhere.

5. I think just getting any chance to work with kids...Personally I don't think you can really teach like, verbally teach other students to work well with children, you actually have to do it...I know a lot of people, like my other peers, they just don't really understand how to work with them...and I don't know what their frame of mind is because they...treat all kids like they're adults, which doesn't work really. So I think really getting out there and doing, and working with them is the only way you can really fully understand how their brains work, what their emotions are, and all of that stuff. And then least helpful...I can't really think of anything that's least helpful. I guess...

\section{$A L:$ Were you able to come to any of the trainings before the summer?}

Yeah. I came to the three trainings that were before the actual camp started. And those were pretty good. It seemed like the first one was pretty basic, and a lot of the counselors there had already worked with children. But it was still good for some of the other counselors to gain more of the just general knowledge about different things, working with children.

6. Well this has only been my second or third time coming to this park. I've just biked through here a few times. And I didn't really understand...it seems like there's a really good community around here, and that people are really trying to change things around here. So I guess my impression would just be that there are people here that actually want to make a change and I'm really glad 
there's a camp here to let kids know about different environmental issues like this... I'm a big fan of parks and State Parks and National Parks anyways, so I guess my general impressions of parks kind of follow the same, just how well they're run and for the most part, how they're kept and managed.

7. Yeah, a lot actually. In about fourth or fifth grade I had a student teacher from Lewis and Clark that kind of introduced me to a lot of environmental topics and then in fifth grade I just got really, really into the environment and then I watched the movie, The Inconvenient Truth, which made me do a lot of thinking. And actually I talk about, with my parents mostly, about just what's going on on this planet. So this is definitely, environmental issues are not a new topic to me and I am interested in what's going on with them and... It matter to me... It's something that I think is very important that is overshadowed by a lot of other things.

$A L$ : And do you feel that you talk about these things more now that you've been to camp, or is it about the same?

Strictly the environmental issues, I would say it's about the same.

8. That's actually a really interesting question because at the beginning of the summer I probably would have said if they were adult supervised or counselor supervised I would have said it's fine, but then I think you were the one telling me about the recent problem with pollution and then how they're doing the pipe work on it and they they're trying to get the trout to come back up. So my opinion on that would definitely be changed to say it's probably not a good idea anymore because even though the kids don't really... If the kids learn that it's okay to do at camp, then they're going to bring that state of mind everywhere else they go, which could lead to them just thinking it's okay to do. Which probably isn't the best idea when you're trying to keep it clean and there's plumbing and you're trying to get an animal population back. So yeah, it definitely has changed this summer, so I'd probably say no by the end of the summer.

AL: And just in follow up to that, do you think that there are times when the value that the kids get from having that experience of playing in nature would outweigh that?

That's a really good question too. Hmm...The first week, it seemed like the kids really were stuck on that idea because a lot of them had been there before, so they knew that in the previous summer they could do it. But then in my second week it didn't seem like going in there was as big of a focus for some of the kids. So I think it just depends on the students you're working with, but in general, I don't know... I think maybe part of the whole camp is teaching about environmental issues, so if you're teaching them to go in there that's kind of taking back from what the whole idea of the camp is. So I would probably say that you just need to explain to the kids why you're doing what you're doing because without explanation they're not going to really understand why you're not letting them go in.

9. I don't really have any particular places that I've been wanting to work at, just any environmental areas I think are interesting. But I think more of just a nature point of view. I'm more interested in... agricultural and city based environmental issues... What they're doing at State Parks and National Parks is great and really important, but the truth is that...not enough people are aware of what's going on in the parks, there's too many people that are strictly from the city and they don't understand what's going on in the city. So I would be more interested in working where there's the bigger problem, rather than here. But that's not to say I wouldn't want to, I'm just saying I feel like there's a bigger need elsewhere. But what they're doing here is really great too.

10. I think just being out in the wilderness...the more time you spend, you just become more aware of what you already know. It's not necessarily you're learning new things, but just strengthens your 
view on what you see going on. And that's the same thing for Outdoor School too. My first week was a little bit of a struggle, but then my second week from Outdoor School was really great and I think I took a lot more, not just environmentally but also just working with the children, just spending time and learning from them, you take away a lot from that.

11. I don't know if I would call myself an environmentalist, but I'm definitely interested in what they do and things like that.

\section{AL: So what do you think an environmentalist is?}

That's a good question. Umm.... Well I guess maybe officially if you're an environmentalist you've probably gone to school for, or gone through college and maybe gotten your degree in something environmental based, but I think people that care a lot about the environment could also be considered environmentalists, too. So, then I would consider myself one, depending on your definition of it.

FINAL COMMENTS: It's just been a great pleasure working here this summer. I can't wait till next year.

\section{Interview with Hazel, August 26, 2011}

1. It's hard to think of a specific thing.

\section{$A L:$ What was the first thing that came to mind?}

A couple of days ago I was going on a hike with Sunshine [staff member] for afternoon activities and there were these two boys in the back and they taking a really long time. They kept on stopping and talking. And I was like, "Okay guys, you gotta keep going," and all of that, and they like, "But, well we have a secret." And so I said, "Okay, what? Can you tell me?" and they were like, "Yeah, but you have to keep it a secret." And it was a big deal. And they ended up initiating me as one of the dragon club. And so for the whole time they talked about how dragons can have long distance energy healing. And I thought it was really awesome. So, that was probably what made me smile the most. At least.

2. Probably last week with Alex and Neil and Silas [names changed] and I don't even know if I have a specific thing... Maybe that day that we were having lunch and they were crazy. That was definitely challenging. Just trying to get their attention in the first place to even be able to say anything.

3. Well right after I got home from doing Outdoor School for the first time I was really excited about it and I wanted to have something else to do in between then and next fall, so I was talking to a few of my friends and they had heard of the Tryon Creek Camp and I thought I would check it out and it was definitely a different experience, but in a good way, so I think I could go back to Outdoor School and have a completely different perspective on it now and it would be really good.

4. I don't know if it was even something specific I learned, but just more about how interested all the kids were in everything... I don't know of a specific science thing that I learned, but ... I really learned about how everyone else perceived it in different perspectives on different concepts.

5. As far as most helpful, talking about, at the thing you did, just talking about how the kids would actually be acting, instead of just you know... just a handout that's like, "Well say this if they say that."... Cause that never really helps. So I think just actually being able to talk about it and spend 
a lot of time on that.

\section{AL: What was least helpful?}

I think when we made those, um what did we make... was it the ethnobotany thing? Where we made those... It was fun. I don't think it was incredibly helpful as far as what we were gonna do at camp, but it was interesting.

6. Well before this I had only ever come here every once in a while with my family and we wouldn't ever really go to any specific places or think about it as a science or learning experience. It was just, okay we're gonna go walk around some pretty place and it will be fun. So I really enjoyed learning about the history of the land, cause I never knew any of that and also just knowing my way around was really great. And I think it's a pretty amazing place instead of just a pretty place to walk around. There's a lot more going on.

7. Yeah, I think before I came to camp I was interested in most of those things ever since I was pretty little, especially like recycling and all of that, but then it was always sort of in a vague way. And now I have more of a specific thing to tie it down to, and I definitely talk about it more often now with my family. So, yeah.

8. I think before the summer began I would of said, "Definitely." Cause it's really fun and I remember going to camps and things, the most fun is when you can just go and play, and get all wet and dirty and all of that. And now I think I understand why they aren't supposed to. I do think that it would be fun if they were allowed to a little bit, but I mean it makes sense that they can't. But I do think maybe if there were some spots that they could, it would be fun. Cause that's a pretty important part of being in a creek place for kids, that's usually one of the main things that they get excited about.

9. I was always interested in it. I never really thought about actually being a part of it. Now I think I'd definitely be more interested in visiting them and finding out more about the spaces.

10. It's definitely made me want to keep on working with kids a lot. Also, learning more about natural areas and ways to take care of them.

11. (Long silence) I think that as far as I know, an environmentalist is somebody that cares about and wants to protect the environment. And I would consider myself a person like that, but I don't know if I would go around being like, "Hey, I'm an environmentalist!" all the time. So, it's sort of...

AL: Why not?

I don't know. It seems a little bit... (laughs).

AL: Do you see why I saved this question for last? Maybe? (jokingly)

Maybe.

AL: But what were you going to say? It seems like...?

It's just a bit odd. I mean, I agree with it. I think it's a good concept. So, sort of.

AL: What would you consider an environmentalist? Or how would you define one? 
An environmental steward... Someone that is actively involved in caring for and learning more about the environment.

AL: Will you say that one more time?

Someone who is, what did I say? (laughs)

AL: It's okay, it just got noisy in here and I really hope it recorded.

Someone who's actively involved in caring about protecting and learning about the environment, I think.

AL: That sounds close enough.

FINAL COMMENTS: I've just been thinking about how I think that working at a day camp is a lot more challenging than working at an overnight camp because you're not as focused as you are when you're at a place solely for that purpose, instead of how at a day camp you're like, "Okay well I'm gonna go here and do this, and then later I'll deal with everything else." But when you're at Outdoor School or at some other camp you're very much present. And I think that that really helps when you're trying to teach kids anything, cause when you're completely... all of your energy is directed towards that.

\section{$\underline{\text { Interview with Zoe, September 9, } 2011}$}

1. With the full day doing the skits and songs in the mornings. That was really fun. Usually I'm not one of the people who like to go out up in front of a lot of people and lead things but that was really fun and the kids really like it too. So I always liked doing that. And also just talking to the kids one on one. Cause you get to hear their opinions, what they have to say at that age, and I can relate to that cause I went to camp here when I was that age too.

2. When certain kids don't listen to you or pay attention. That would probably be the most frustrating because either they run ahead on a hike, or if we're having a big group conversation, they'll be talking to their friend or not even paying attention.

3. I haven't worked at other camps before... I went here for years as a camper and then the last year that I went to camp I heard that I could volunteer here, so I really wanted to do that, cause I had so much fun when I was a camper.

4. The ecology where if one animal or plant is eliminated how it affects the entire forest or ecosystem, because sometimes it's hard to grasp that entirely. Because I had Biology for science last year and we studied that, but I never thought about it too hard until we talked about it at one of the trainings... It's really interesting and that was one of the main points that I wanted to teach the kids that we had here. Even though it was kind of hard, especially with the younger ones, to have them understand it.

5. ...For the most... the age groups that we studied... With the certain age groups we had their behaviors and what they might act like. I think that helped a lot, because you kind of had a feel for what to do to deal with... Least helpful, I would probably say that the very first training we had. It did just do an overview of things you needed, which was kind of basic. So I feel like I didn't really need that.

$A L:$ Was that the one in the middle of the springtime? 
Yeah, it was. And we met in here [the classroom at Tryon]. I think it's mainly for beginner camp counselors.

AL: Okay. How many years have you been coming out here?

This is my second year [as an $\mathrm{AC}]$.

6. ...It changed more this summer than it did last summer... I feel more grateful to have it here... I know where I live, like right in my backyard, we have this forest that we can go hiking in, but it's so cool how it's in the middle of an urban area and a lot of people can come here... I don't know if you met her but, someone's granddaughter or cousin or something came here for a few weeks from the east coast. Do you remember, what that Red Cedar's...? ... She was saying how in the East Coast they don't really have parks like this, that they can go to just like right by their house, or they can drive... It just kind of put in perspective of how lucky we are to have this. And how so many people care about maintaining it and keeping it able for people to use, but still all the wildlife here.

AL: It's pretty amazing all the stuff you can see right here in the middle of the city.

Yeah it's really cool! I like this park.

7. I'd say I do talk to them more. We just started composting this summer. When we were doing the overnight camp I saw how with every meal we had, we put something in the recycling bin, or the compost bin, with all the worms. And that was kind of cool cause... when we make our meals, we don't really think about exactly what's going to be going to waste. It was kind of cool to see how you [AL] made food. Cause it was so... it was healthy for you and it was really good for the environment. So it was kind of cool to like see how you could do that and still have it be really good in nutrition, wise for you too... We do recycle quite a bit at my house before we went to camp. And I think my mom just started getting into trying to keep toxins, like outside toxins from coming inside our house, for like our own benefit. We have been trying to conserve energy with lights and getting certain types of lamps that will preserve energy. But I think the main thing that we've changed over the summer is the compost...We've had a compost bin for years, but we haven't used it. Then this is the year that we actually started using it, and it's worked out really well.

AL: Nice. Are you guys going to use it to fertilize the garden?

Yeah. My mom loves to garden, so it's like a win win.

8. I think kids should be allowed... If they grow up not being able to play in nature, they probably won't have as much respect or love towards it... I grew up coming here a lot and I feel like once I'm older I can relate to it and be like, "I was here and now I'm going to help the park." So I definitely think kids should be allowed, but at the same time not go off trail unless they're allowed to. And, yeah I think they should. I think I would have answered the same before, probably because I came here when I was a lot younger too, so I knew how much fun it was here.

9. Before, I don't think I really was interested in... at least working in other state parks... When we were here I would talk to the rangers and I asked them what it was like to be a ranger. I think it would be a really fun job to have... I do like visiting other national parks and state parks, just cause they're fun to go hiking in... I think because I have such an attachment to Tryon Creek, that this is the one I'd like to work at... But, yeah, I would still like to work at other ones. So, it has changed, yeah. 
10. [AL: I know you kind of already touched on this with composting...] I'd say even just like daily habits. I read somewhere that keeping your phone charger and toaster plugged in all the time, it still slowly leaks out energy that you're not using. So I've been unplugging those when I'm not using them. And also, definitely working with kids. I just started babysitting for a few different families on my street. I've definitely noticed that I've been teaching them camp songs and we've been going out in their backyard and playing, and with one of them we even started to garden which was pretty cool... I think just being outside more, and mentally, in the back of my head, always thinking about, "Is there a way that I can change this to make it better for the environment?"

11. I think an environmentalist is...someone who pays attention to what's going on with the environment and how what we're doing to the environment affects it. Isn't an environmentalist like sort of like stewardship, like what we did before? You think? [Zoe asks $A L$ for clarification.]

\section{AL: This is your opinion, for now, so...}

Well I kind of think it is like stewardship [sounds more confident]...being respectful to it and trying to have ways that we can use the environment, but not in a harmful way. I could kind of call myself an environmentalist [sounds hesitant]... I'm aware of what's going on, but not in like a huge picture, more just like locally. So, in a way, yeah.

AL: Who do you think could call themselves an environmentalist? In your opinion? Or what characteristics would they have?

I think even the people who work here, like the rangers... I think people who teach other people how to respect and help the environment in a way that's still not drastically...even just for everyday use... like that can change... and overall help the environment. So I think like the people who work here who go on the trails and help it so people can still go on the trails and be in nature, but still not go off trails.

FINAL COMMENTS: I think the overnight thing, the training, was really good. That was a lot of fun. Especially the night hike, that was so much fun. I think doing that in future years would be good. I'm really surprised a lot of... not very many people signed up for that.

AL: Yeah, I was hoping to get more. I think a lot of people were out of town, and a lot of people that were in town just didn't know what to expect and didn't come. So, oh well.

...I think you did the best you could to like advertise it.

AL: Yeah, I'm not sure what else I would have done.

I mean, you even had the schedule printed out, so they could look at that, but... I definitely learned a lot from that. A lot.

\section{$\underline{\text { Interview with Celia, October, 10, } 2011}$}

1. Just...the experience of working with the kids and having them look up to you.

2. Probably...keeping those rowdy kids in line... The kids are hard to handle or situations that you don't know how to deal with. 
AL: Is there one that stands out in particular that you can think of?

No, most of them were pretty fine, it was just like, if they got tired and you have to like persuade them to keep on walking or things like that.

3. Well, first I was gonna do it with my friend [name omitted]...cause she needed community service hours and I was like, "Why don't I do it with you?" And then it just turned into an activity rather than just like community service. It was just more of like something to do, so that was pretty fun.

AL: Have you worked at other camps or worked with kids before?

I haven't worked at other camps, but I have worked with kids, like babysitting and just watching....and like volunteering in schools.

AL: Tell me more about that. What did you do in the schools?

Well my mom is a principal at a school, so sometimes I go and just help out in classrooms, but not a lot. And then I babysit, on top of that.

AL: Do you do like, tutoring or help with behavior issues in the classroom, or...?

No, it's more of like with the teachers.

AL: Oh, like helping them get stuff ready?

Yeah...and I also work at a Sunday School on Sundays, in a classroom with kids, so...

4. I felt like I learned more from your training than like being an aide. Like when we went out on hikes and did activities inside.

\section{AL: Does anything stand out? Or something that was interesting to you?}

Interesting?...I actually liked the history part of the Tryon Creek, and like the little stuff too, just like the random facts when you're hiking and someone points out something. That was just a part of it all too.

5. The aide training, when all of them got together...It was okay...just coming up with songs... I don't think we learned that much about like actually what to do... we wandered the trails and sang and few songs, but I don't think that was that helpful, but it was still useful. I did learn a few things when...they were talking about early development, like those worksheets. That was a little helpful, but it didn't really come in to use because I was working with a little older children, like in first grade rather than younger. Your training, I thought it was more about the nature rather than the actual being an aide, and it was fun.

AL: Did you feel like it ended up being useful when you were teaching them?

It was useful for the nature facts, if someone asked a question, but that was (it?)...

6. It feels like since I kind of live around here...I don't feel it's just like, “Oh there's Tryon Creek. [in a bored tone] "It's like, "Oh, I remember when I used to work with a nature day camp. [In an excited tone]" It's more... I feel like I know it better. And it's not just like something you pass every day or something. I don't know how to explain this. It feels more, I want to say connected with it, or... it's become more a part of my life. 
AL: Have you been out here this fall yet at all?

I haven't. Yeah. I will start though because I take photography and this is a great place for photography, like pictures.

AL: Yeah, it is good for that.

Yeah.

7. I don't think we've ever had...just sat down and talked about it, but I think it's...part of everyday life. Like, go recycle this or something, like when you're done with something. I recycle...

\section{AL: Do you feel that you talk about these things more now that you've been to camp?}

I don't feel like I talk about it a lot, but if it is brought up I feel like I know a little more about it than I used to, and how it does affect our environment.

8. I don't think so, because first of all for safety... If there's stinging nettles or they don't know what to look out for, and also they're trampling over plants and stuff. That's not good for nature in general, and just the damages they could do, and things that could happen if they're not careful or know what to look out for. They could get hurt. The environment around them can get hurt. So I don't think that's a good idea.

\section{AL: Would you have answered the same way before the summer?}

I don't think so actually. I wouldn't have thought through it so thoroughly.

\section{AL: Can you think of any positives to having them play in the creek? (And if not, that's fine.)}

They can, let's see, I know there are some. Fun in general. They can learn from outdoor activities. Better than playing inside.

9. I don't think I'd really thought about it. I was looking at, for some volunteer opportunities. When this came along, I was like, "What a great idea." And it's with kids too, so you're not working in like a boring office or something, so that was definitely a win-win. But, I don't think so.

\section{AL: Has your level of interest changed after this summer? As in visiting or working at parks.}

Definitely for...visiting. Since I kind of know about the trails more often... I feel like if I came here alone to go running I would know my way around...Also, in general I guess it's more interesting than just like going for a hike... I feel like I know more about what's out there. Like, "I know what that plant is, or what that kind of tree is."

10. I definitely have a lot more respect for the environment... You know when you're walking down the street you pull leaves off of a tree or something like that, I don't do that anymore... Working with the kids, I thought that did give me a lot more experience, and I knew how to handle big situations cause when you babysit, you're used to one or two kids, but having like ten kids at once you do get a lot more experience and you know how to handle more things so when you're going into another situation like that, it doesn't seem as like, so hectic... And you're more calm.

11. Probably like in the middle here... I'm definitely not a whiz here, but I do know like a few more things than I did going into the summer, about the environment-more knowledge about how it 
works, like the stuff behind just like water and trees and plants, but I don't know everything, I know that.

AL: Maybe an even more important question, in your opinion, what is an environmentalist?

Someone who has... knowledge about the environment, and they're educated about the environment, and they can educate others. I'm going to come home and think of something totally better, but.

$A L:$ No, this is great.

...Kind of along those lines...I'm sure that's so broad, but... You know it, and you can let other people know about it too.

FINAL COMMENTS: I thought I had a blast. Just in general, like with your activity...your thing, I don't know how to... study, the overnight. And then just working with the kids and stuff. That was pretty fun.

[Casual discussion about how the staff really liked Celia. Celia mentioned how she really wants to do Outdoor School and get to work with the $6^{\text {th }}$ graders].

\section{Interview with Liza, October 14, 2011}

1. Well I have to say one of my favorite memories was my first week when I was working here, and I got to work with the half day kids, so the really little kids. And there was this one girl, and she... was totally in love with me and she was like hanging off of me throughout the whole week... On the last day she was like, "I love you, [Liza]!" And she just like gave me a big hug before she left, and I thought that was really cute.

2. ...When I was working with the slightly older kids, my second week... I was having...trouble because some of the kids kept getting really rowdy and I was kind of having trouble keeping them under control, like when my counselor would go to the bathroom or go to get supplies, and then they would start running around and I couldn't get them to just like sit still and actually like play a game.

3. So this is my first time. That was my first time ever working at a camp... I kind of want to be a camp counselor at some point, because I've been to summer camps myself and I always like thought that counselors...were...my role models. They were always all super nice and so I always really remember them. And so I wanted to learn how to be a really good counselor so that way...if I do get a job as a camp counselor, then kids will feel the same way about me that I felt about my camp counselors.

\section{$A L:$ Where do you think you'd want to be a camp counselor?}

Probably Camp Namanu, because that's where I go to summer camp.

AL: Yeah, that's a really great camp. How long have you been going to Namanu?

I think last summer was my fourth summer going. I skipped one year in between summers. But I've gone for four different times.

AL: Have you thought about being a CIT there? 
I really want to. It's kind of expensive, but it sounds like a lot of fun.

4. I think the most valuable thing would be learning how to identify plants better, especially things like stinging nettle and like plants that you don't want to touch or you want to stay away from. Or then also plants that can be useful...

5. I think the most helpful thing was going over the schedule and how everything was gonna work out and kind of planning things out before we actually had our first week. And, I don't really know exactly what the least helpful thing was. Maybe it was...I don't know...

6. ...I didn't know a whole lot about the camps and stuff. I didn't ever know all the things that went on in Tryon Creek until I did it last summer and so I felt like it was cool to actually just learn like all the work that...gets put into it every summer to do things like that.

$A L:$ So do you mean all the work that goes into actually planning the camp programs?

Yeah.

7. I think we did sometimes. It wasn't necessarily like something we would talk about all the time, but we would sometimes talk about things like that. Especially like global warming, in my science classes. And so then we would discuss it at home. Like whether it was actually a big issue or not, you know the whole thing where some people believe it isn't, some people believe it is.

\section{AL: Do you talk about these things more now that you've been to camp?}

Yeah. I think so... Now that we've been out in nature more, I think we do kind of discuss it more often.

AL: More with your family, or friends, or both?

Probably more with my friends, cause we talked about it with my family some, but then it's like I never really talk about it with my friends, but then I started talking about it more.

8. I do think it is a good idea to have kids play out in the woods, especially if they're learning at the same time, because... my family would always like go on hikes when I was younger and even though I didn't want to go, I would always have fun when I did, and it kind of made me start to like nature more... It's good to teach kids about conserving nature. If they have fun out in the woods and if they want to keep having fun they need to ... help conserve it.

\section{AL: Would you have answered the same way before the summer?}

I think I probably would have answered it the same... A lot of the time I never would really look forward to getting out in the woods, but then when I did do it I always ended up having fun with it.

9. I don't really think I ever thought about it very much before I started this summer. So I never really gave it much thought whether I wanted to work there or not.

\section{AL: Do you feel like your level of interest in working at or visiting parks has changed after this} summer?

Yeah, I do. I thought it was really cool to be out in nature... every day for two weeks... It made me really like it and want to come back here more. 
10. ...Working with kids, I'd probably try different things, cause I'd done some babysitting before, but I've never really had to be in charge of a group of kids like all day. So I think some of my tactics for getting them to calm down and getting them interested in things, even if they weren't so excited about it, has kind of changed. It's given me more ideas for how to work with difficult kids.

11. I guess I sort of am. I mean I do really care about the environment and I want to conserve it because I really I do like being out in nature, and you know, it's kind of scary to think about the whole global warming climate change... I do try to tell people about it, and I have a strong opinion, but ... I'm not really involved with any environmentalist groups.

\section{AL: In your opinion, what is an environmentalist?}

An environmentalist I think is someone who cares a lot about the environment and is like involved in ways to help conserve it and to help inform other people about the issues that are going on and ways that they can help.

FINAL COMMENTS: Overall, I thought it was a really great experience. Especially like my first week here, cause I felt like I could work really well with my counselor. And then I felt like really proud of what I'd accomplished. And then the second week I thought it was okay, but then I sort of, I felt a little disappointed at the end of the week, when I got my results sheet back... The counselor graded me pretty low on almost everything. And she was saying it was mainly because I hadn't really worked here before, and so she gave me averages just cause I'm new...I felt like I'd worked hard and that I should have deserved like what I'd gotten the previous week, which was like mostly higher. But that was the one negative thing I had, but everything else was really fun.

\section{$\underline{\text { Interview with Megan Hadley }}$}

1. I think it was my second or third day working with the full day campers, and we were talking about the forest canopy that day, so that was pretty cool. And just as we were starting our hike, I thought I glimpsed a pileated, which is always really cool. And then.... little ways along the trail we spotted a great horned owl, which was really cool and all the kids got really excited.

2. It was kind of a series of things...One of the half day campers did not have any interest in walking with his backpack on, but then when we would take it off, he would run off down the trail and we wouldn't be able to keep up with him. So, it was kind of like, well, "I guess we'll just have him wear it and have him complain, because if he's running down the trail we're not going to be able to keep up with him."

3. I think it was mostly at the suggestion of my parents, and it was also just a good experience for me- just working with kids. I've had some experience because my mom babysits, but it's just good job experience. It's kind of working with other people in a group for like a week at a time is just a good experience.

4. ...I'm not sure. I remember a lot of cool things that we saw. I don't remember too much science content that I heard about that I didn't know already, because I've taken several other science classes in school. Like when I was working at Tryon last summer, I'd just gotten out of Chemistry at [my high school], so that was pretty cool. And I took Biology the year before.

\section{AL: What were some of the cool things that you saw?}

Well the owl was really cool, and we also, when I was working with the half day kids, we saw a bird's nest, a robin's nest, and the little babies were very, very, very hungry. And it was very cute. 
It was hard to spot. Actually Liza saw it and mentioned it to us, and then we walked by that area and I was able to pick it out and the kids got really excited about that too.

\section{Al: Was it down by Red Fox Bridge?}

Yeah, I think so...There was one tree, like on the bridge. It was covered with moss and there was like a little cup shape on the side...

5. [Most helpful] I guess just having my mom working with kids most days of the week was just good. Though the kids my mom works with are usually a little younger. So that was good to just have that kind of background knowledge... At the trainings it was good know that I wasn't just going to be in charge of a group of kids by myself. That was like one of my worries at the beginning that I'd be like in charge of kids without instruction. And I'd like get them really lost or something. So, that was my one concern, but it was nice to that I'd have someone else to work with.

[Least helpful] ...They could of given us some song or game ideas to play with the kids... They did a little bit, but like sometimes when like when my instructor was a ways away I wasn't always sure what to do to keep the kids occupied.

6. I think I've just gotten to know it a lot better, which has been really cool. Like I've walked around here before, but it had been a couple years since I'd been back. So it was just kind of nice to be just in the woods for multiple hours every day. It was just a really cool experience, to just be walking around in all those beautiful trees with a group of mostly happy kids.

7. Well we do recycle a lot as a family. And we compost a lot. I don't know, we don't really like have discussions about it all that much though...it's sort of just become part of what we do at home, so it's not really something we talk about all the time

\section{AL: What about with your friends?}

I don't know that we really talked about environmental things all the time. Like if we learned something in class that day then we might discuss it, but other times it just didn't come up for one reason or another. Like something was coming up in school or people were complaining about homework and such.

\section{AL: Do you talk about these things more after having worked at camp, or it is about the same?}

I think it's probably about the same.

8. I guess I'd say it probably isn't the best idea to just let them have kind of free reign just in like the creek area especially, just because that would kind of upset the environment and you know, if one of them fell in, they'd be really sad and then you'd have a wet, sad kid to deal with, and that wouldn't fun. I'm in northwest ecology this year, and we're learning a lot about water quality testing. And we're going to be working along Crystal Springs Creek this year doing site visits, like two or three a quarter...observing the water quality and that kind of thing. So, we're learning a lot about different things that upset water quality, and like human impact is a really big one. Everything from runoff and industry to just people being in and around the creek.

AL: Do you get to do a lot of field trips for the class?

Yeah, we're doing five field trips as a class, and then I think ten site visits on our own time. So we're spending a lot of time around the creek... 
AL: Would you have answered the question the same way before the summer?

I don't know. I don't think I would have, maybe. I probably...wouldn't have because I didn't know quite as much about just the way people affect delicate ecosystems like creeks and forests and that kind of thing.

9. I always love being at wooded places like this. It's just a great relaxing place to be, and you're never really sure what you'll see. So, I always like coming to places like this. I haven't really thought about working at a park necessarily, but that could be a really cool job.

\section{AL: Do you think your level of interest has changed over the summer?}

I think maybe it has a little bit, just from experience of working at a park. I still love like being at places like this. I don't know that it's changed a whole lot, but the experience was a really great one.

10. I think working here did help like when my mom has kids over that she's working with, like if she needs to be away for some reason, I have a little more experience working with kids, so I can maybe keep them entertained a little easier. I'm not sure about sustainable life choices. We already do a lot of that at home. It's kind of cool, I have one of those twirly fluorescent light bulbs... I don't know if that's the right term, but it's lasted for like four years. I haven't had to change it. So that's pretty cool.

11. That's a hard question! I guess I'd call myself something of an environmentalist, just because I've always think that taking care of the environment is really cool... In both of my science classes that I'm taking this year, I'm learning a lot about how things that we're doing are affecting the environment. So I guess just kind of learning about that is a really cool experience and it's just good to know that like things you do change everything else around you, like little things can change really big things.

\section{AL: In your opinion, what is an environmentalist?}

I guess an environmentalist is anyone who thinks about what they do and how it affects the world around them, and tries to make changes that will support the world around them.

FINAL COMMENTS: I just thought it was really great experience to be working with all these kids who were just so happy to see you all the time. Sometimes I felt like I didn't get quite as close with my kids as like Liza did, but I think that's just kind of how I am as a person. I'm just kind of quiet and not necessarily really outgoing and excited all the time, like Liza is...I think that helped to make me somewhat more that way, just more outgoing and willing to talk to people.

\section{Interview with Adam, October 21, 2011}

1. As a counselor, my favorite memory of camp was probably going to the Terry O'Reilly Bridge and letting the kids play all the games that they have fun doing.

AL: So you said "as a counselor"... what was your favorite memory as a kid?

I never really went here as a camper, but I would go through the park myself as a kid going on small hikes. And I really wouldn't go all that far, just around Iron Mountain Bridge.

AL: You live pretty close to the park, right? 
Yeah. After it goes past the Iron Mountain Bridge, it kind of goes along Country Club and it goes through my backyard.

2. The most challenging and frustrating moments were probably keeping all the kids together as a group, cause they will tend to wander off whether or not you tell them to stick together.

3. Originally last year, my mom thought it might be a good idea to volunteer, cause I used to volunteer at the library signing kids up for summer reading, but I was kind of getting a little bored with that and she thought this would be something fun to do for a change.

\section{AL: And were there other times that you've worked with kids?}

Not really, when they're much younger than me, but in my Boy Scout troop I have led a couple of camp outs.

4. I learned a lot at camp about the different kinds of streams, and the factors that... can hurt them or make them better for fish... I learned that the streams are slightly acidic if they're anything other than usual, and that they are often... that the perfect stream is a $\mathrm{pH}$ of 7 and dissolved oxygen and parts per million of around 8 to 10 .

5. I came to the first training but I wasn't able to go to the second one for a campout. But the first training, it didn't seem like it helped that much if we've already done the camp before. It was basically songs and games and things to keep the kids busy with.

\section{AL: You felt like you did get the songs and games, or that's all it was?}

I felt like that's most of what it was.

\section{AL: Do you have any suggestions for what would have been helpful as a returning $A C$ ?}

What might have been helpful is a little more in depth session talking about... interesting things to talk to the kids about or going around, learning about different kinds of plants.

6. After doing camp for a couple of years, it's kind of expanded what I've known of Tryon Creek. Cause I used to just know a little one mile loop that I would run around every now and then. But now I know about different trails, the different kinds of habitat that there are for different animals around Tryon Creek.

7. We had talked about... well my family is... we're pretty conservative with how we live. But we talk about that a little bit, but I don't think that's changed too much from being a counselor.

\section{AL: So you don't feel like you talk about it any more now?}

Not really, cause we didn't really go and do too much of that as a counselor.

\section{AL: How about with friends?}

With friends, our Boy Scout troop tries to be really conservative when we go camping. But I knew a lot of stuff already.

8. I think it's a good idea, in the sense that the kids are getting to have a little more fun and excitement at the camp than just walking around learning about plants. But I do think that the park should limit it to certain areas so that it doesn't disrupt the foliage or plants in other areas. 
AL: Do you think that you would have answered this question the same way before having worked at camp?

Not really, cause I didn't know too much about not running around off the trail. And me and my friends did a little bit of that before I really knew how much it hurt the plants.

$A L:$ So you guys don't do that now?

No.

9. I hadn't really thought of working at other parks, cause most of them were pretty far away and this was the closest one. And I didn't know that you could work at other State Parks before I found out about working at Tryon Creek.

AL: Do you feel like you level of interest in working at and visiting parks has changed after being an $A C$ ?

I liked parks before, but I still like them about the same amount.

10. I probably...well I learned about just having to be patient, cause sometimes you can't exactly expect the person you want to do something to do it right when you want to. And it's also kind of helped with my knowledge of how to handle kids better.

AL: And what about in terms of like daily habits as far as sustainable life choices, or environmental concerns?

Well I know more about...I'm not really sure that it had that big of a ... that it made that big of a difference.

AL: Okay. Well it sounds like you have always been really interested in being outside and that your family and your Scout troop is pretty environmentally conscious already.

Mmm, hmm.

11. I would call myself kind of a mild environmentalist, not exactly the kind of people that go and protest logging, but kind of using that as an example, but I'm... I do try and recycle whenever I can and not hurt the environment.

AL: In your opinion, what is an environmentalist?

I believe than an environmentalist is someone who puts the wellbeing of a forest or a natural environment before gain that could be taken from harming the forest.

FINAL COMMENTS: It was really fun getting out in the forest, cause otherwise I probably wouldn't have done that much during the summer.

AL: Do you mean in terms of having activities or in terms of getting outside in forest specifically?

Probably... activities, cause I do go camping fairly often, but other than that I probably would have just stayed home and maybe had some friends over for most of the days in the summer. 


\section{$\underline{\text { Interview with Owen, November 18, } 2011}$}

1. Probably camouflage, just playing games with the kids. Especially the ones where we can actually teach them things. That's really fun. Probably just camouflage at the elephant tree.

2. The second week I had [camper name omitted], and at one point he managed to get ahold of a very large stick. Mostly just having to be firm with the kids, but you're not allowed to yell, you're not supposed to yell, you shouldn't yell. So, just trying to be firm, but not aggressive is the probably the best word for it.

\section{AL: And did you feel like it was a learning experience in that area?}

Yeah. I felt like...it taught me how to... this word's going to seem really ironic, when I think of it, put my words into, thoughts into words, and really teach them, er direct them... what is that word?

\section{AL: I'm thinking articulate things.}

Articulate, exactly.

AL: Is that what you were thinking?

Yes, articulate my thoughts.

3. At the very beginning, a couple years ago, I think I just needed something to do over the summer. But what's been bringing me back is just, it's really just fun being with the kids and I actually learn a little bit myself each year. And I feel like it's a great use of my time over the summer.

\section{AL: Have you worked at other camps before?}

No...I don't think I have actually.

4. Mostly the invasive species work. I feel like I know a fair bit about the environment, but I feel like the invasive species work taught me a considerable amount about the environment as a whole, and actually northwest flora and fauna, quite a bit as well. I feel like that was the most informative.

5. To tell the truth, from my memory the games, being able to engage the kids, really helped. This...probably is just me, but its safety rules and regulations I feel like I can...enough common sense to not violate most of those rules in the first place, but I do feel like they're vital, just not for me in particular.

\section{AL: Was that something that you guys went over in one of the bigger trainings?}

Mmm hmm.

\section{AL: Was it State Park rules or just camp rules in general?}

Mostly camp rules... There were a few like, "Don't go off the trail unless instructed." And "Stay away from the creek."

6. Well in the beginning it was just another state park. I actually felt it was a little more developed than the few I've been to, but when getting farther into the forest I really saw how developed the ecosystem was and I feel the camp also helped me with that. 
AL: What do you mean by developed?

I thought it was just...industrialized, not industrialized, I guess industrialized, part of Lake Oswego. But when we got farther in I saw that they had a considerable amount of species that treated it as home, and how it was a very old forest, or at least most of it, some of it.

7. Before...I come from a family that recycles and composts everything, so not too much in that aspect. But I did talk a little bit more to my friends about it. I wouldn't really bring it up like, “Oh, here's a good topic of conversation: environment." But, if I ever heard a misconception I would try to give my personal opinion and what I believed. I feel like I became, talked more about the environment with my friends, but and I guess a little but with my family. The composting and recycling was mainly just with my friends though.

AL: Do you feel like you talk about these things more now that you've had the experience at camp?

Yeah, in general.

8. Yeah, I think it's a good idea... It's really good to have kids getting outdoors, especially in the summer, with all the technology. I do think there has to be some limits, and there should always be parents with them due to the fact that there are certain things that can be disturbed, like the streams as we've seen. But I do feel that the exercise and knowledge that they've been gaining out there is a really important part of Tryon Creek.

AL: Do you feel like you would've answered this question the same way before this summer, or just coming out to Tryon in general?

I don't think I would. I think beforehand I would of probably just said no. It would have went from one extreme to the other... I would have just said straight up "no," or that, like I said earlier, I thought it was more developed and I would of just said "it's fine," because there's no ecosystem there anymore, but there clearly is.

9. Not state parks. Camp Collins, I don't think that's a state park is it?... I was interested in camps. Less state parks, but I was interested in some camps.

AL: Have you been to Collins?

I used to go there.

AL: As a camper?

Mmm Hmm...

AL: Has your level of interest changed after working there over the summers, to be in state and national parks?

It's become less of a time filler and more something I actually want to do. So, I feel like it's encouraged me a lot more to volunteer there.

AL: Just out of curiosity, have you been out to Tryon at all this fall? Have you had time?

No, I haven't. 
AL: I know it's tough with school.

Mmm. Hmm.

10. I definitely enjoy working with kids, so I'll probably do a little more of that, more volunteering. In terms of life choices, I'll probably pick up more trash, be more conscious of what I'm doing.

AL: It sounds like you're already pretty well plugged into those kind of choices at home.

Yeah.

11. To tell the truth, I don't think I would. I see environmentalists as someone who proactively tries to advocate for the environment in ways that just goes beyond your standard life. And while I do recycle and compost and pick up trash when I see it, I don't actively try to get the message out there.

AL: You already answered my follow up question, which is, what is an environmentalist? Do you have anything that you would add to what you just said?

I don't think so.

FINAL COMMENTS: It's just always been an educational and fun experience for me out at Tryon Creek.

AL: And how about the weekend overnight?

That was interesting. There was a very small amount of people. I thought there'd be a few more. But it was fun. I enjoyed it. We were cold... 


\section{Appendix G: EIQ Scores for the Control Group}

\begin{tabular}{|c|c|c|c|c|}
\hline \multicolumn{5}{|c|}{$\begin{array}{l}\text { Table } 10 \\
\text { EIQ Scores for the Control Group }\end{array}$} \\
\hline Name & Pretest score & Posttest score & Improvement & Posttest date* \\
\hline Kate & 20 & 21 & 1 & July 15,2011 \\
\hline Liza & 20 & 20 & 0 & July 15,2011 \\
\hline Josh & 17 & 21 & 4 & July 16,2011 \\
\hline Adam & $10^{*}$ & 16 & 6 & Aug 19, 2011 \\
\hline participant 9 & $11^{*}$ & 14 & 3 & Aug 26, 2011 \\
\hline participant 10 & $17^{*}$ & 18 & 1 & Aug 26, 2011 \\
\hline participant 11 & 12 & 16 & 4 & Aug 12, 2011 \\
\hline participant 12 & $14^{*}$ & 17 & 3 & Aug 5, 2011 \\
\hline participant 13 & 20 & 18 & -2 & Aug 12, 2011 \\
\hline participant 14 & 14 & 16 & 2 & Aug 26, 2011 \\
\hline participant 15 & 17 & 19 & 2 & Aug 28, 2011 \\
\hline participant 16 & 4 & 8 & 4 & Aug 19, 2011 \\
\hline participant 17 & 14 & 14 & 0 & Aug 5, 2011 \\
\hline participant 18 & $4 *$ & 15 & 11 & Aug 12, 2011 \\
\hline participant 19 & $12^{*}$ & 15 & 3 & Aug 5, 2011 \\
\hline participant 20 & $15^{*}$ & 18 & 3 & July 15,2011 \\
\hline participant 21 & 7 & 10 & 3 & Aug 5, 2011 \\
\hline participant 22 & 13 & 20 & 7 & July 22, 2011 \\
\hline
\end{tabular}

